FEEDLOT CATTLE RESPONSE TO RUMEN UNDEGRADABLE

PROTEIN AND DIET FIBER LEVEL OF HIGH CONCENTRATE DIETS

\author{
A Dissertation \\ presented to \\ the Faculty of the Graduate School \\ at the University of Missouri-Columbia
}

In Partial Fulfillment

of the Requirements for the Degree

Doctor of Philosophy

by

JOSEPH WALTER GOLDEN

Dr. Monty S. Kerley, Dissertation Supervisor

DECEMBER 2013 
The undersigned, appointed by the dean of the Graduate School, have examined the dissertation entitled

FEEDLOT CATTLE RESPONSE TO RUMEN UNDEGRADABLE PROTEIN AND DIET FIBER LEVEL OF HIGH CONCENTRATE DIETS

Presented by Joseph Walter Golden,

A candidate for the degree of Doctor of Philosophy,

And hereby certify that, in their opinion, it is worthy of acceptance.

Professor Monty Kerley

Professor Gary Allee

Professor Jim Williams

Professor Mark Ellersieck

Professor Justin Sexten 


\section{DEDICATION}

This dissertation is dedicated to my wonderful family including my beautiful wife

Lori and our kids Landry, Eli, Lyla, Maggi, and number 5; my parents Joe and Mary and siblings Sara, Jennifer and Brian and all other family that have supported me along the way. The road to obtaining this degree has been anything but traditional, so had it not been for the support of you I would not be to this point. 


\section{ACKNOWLEDGEMENTS}

I would like to thank all of my family for the love and support they continually show me. Lori has had to deal with a lot while I have been pursuing this degree and I thank you for sticking it out. I would like to thank Dr. Kerley for his patience, guidance and support over the past several years. I would also like to thank my committee members for their time and commitment.

In addition I would like to thank James Porter for all of his support through my endeavors. His knowledge and expertise are second to none. I would also like to thank Mary Smith for her time and never-ending commitment. I would also like to thank my fellow graduate students who helped over the course of several years in the completion and gathering of research data.

Last but certainly not least I would like to thank my Lord and Savior Jesus Christ for answering prayers and never giving me more than I can handle. 


\section{TABLE OF CONTENTS}

ACKNOWLEDGEMENTS................................................

LIST OF TABLES ......................................................vi

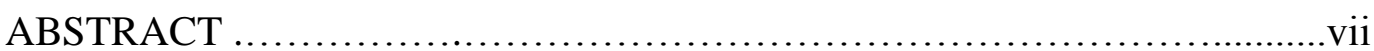

CHAPTER

I. $\quad$ LITERATURE REVIEW ...........................................

Introduction.........................................................

Amino acids overview.............................................

Microbial Efficiency...........................................4

Dilution Rate....................................................... 5

Substrate availability and ATP yield........................6

Dilution rate impacts on microbial efficiency.........................

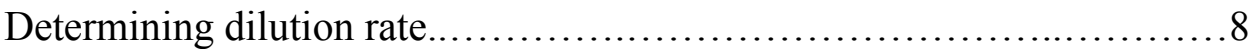

Net Energy and Effective Energy systems.........................9

Determination of $\mathrm{NE}_{\mathrm{m}}$ requirements.......................11

Determination of the $\mathrm{NE}_{\mathrm{m}}$ values of the ration..................12

Determination of the $\mathrm{NE}_{\mathrm{g}}$ requirements......................13

Determination of the $\mathrm{NE}_{\mathrm{g}}$ values of the ration..................14

Assessment of energy expenditure by Net Energy and Effective Energy

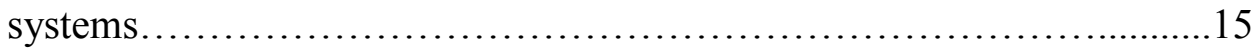

Net Energy and Effective Energy Summary.........................16

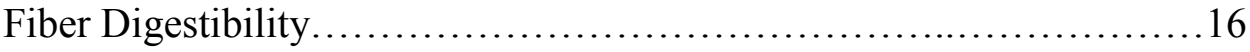


Nonstructural carbohydrates.................................16

Structural carbohydrates...................................17

Neutral detergent fiber digestibility and effect on intake.................18

Impact of rumen $\mathrm{pH}$ on fiber digestion.............................19

Conclusion......................................................... 20

II. BALANCING DIETS TO MEET THE ANIMAL'S REQUIREMENT

FOR ABSORBABLE AMINO ACIDS...............................23

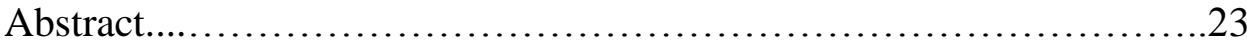

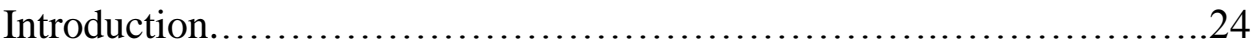

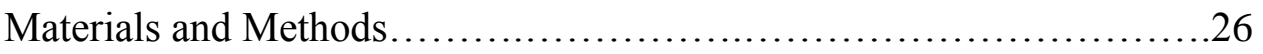

Statistical Analysis............................................28

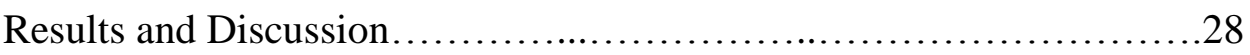

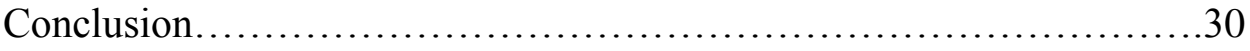

III. DIGESTIBILITY OF FIBER SOURCES IN HIGH CONCENTRATE

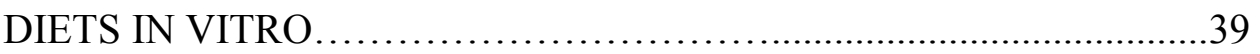

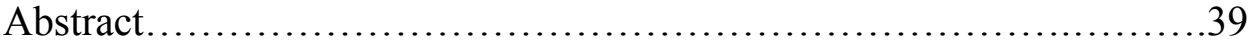

Introduction.......................................................... 40

Materials and Methods............................................... 41

Continuous culture system..................................41

Sample collection and analyses..............................43

Statistical Analysis............................................46

Results and Discussion............................................ 47

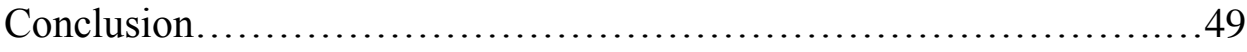


IV. DETERMINING THE EFFECTS OF DIETARY ARGININE

LEVEL ON SUBSEQUENT FEEDLOT PERFORMANCE AND

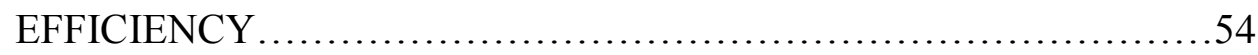

Abstract........................................................54

Introduction................................................. 55

Materials and Methods............................................57

Feedlot steers and management..........................57

Feed intake measurement.................................59

Statistical analysis......................................60

Results and Conclusion........................................60

Conclusion......................................................

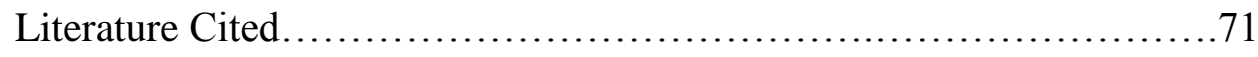

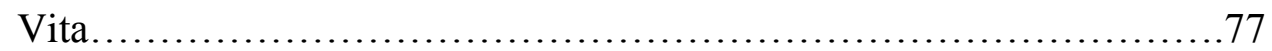




\section{LIST OF TABLES}

Table

Page

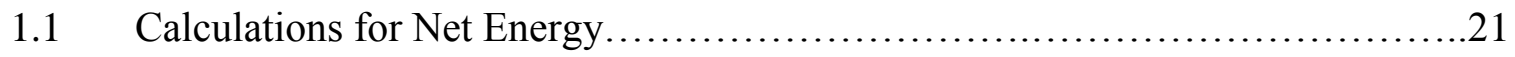

1.2 Calculations for Effective Energy.....................................22

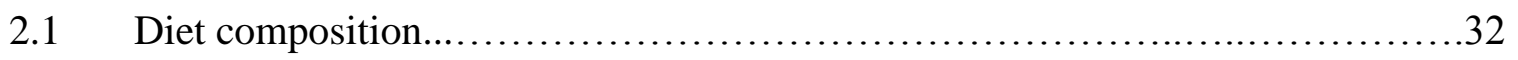

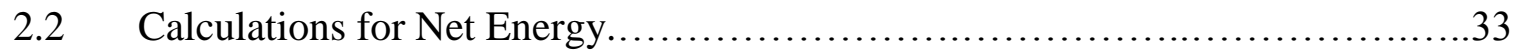

2.3 Calculations for Effective Energy....................................... 34

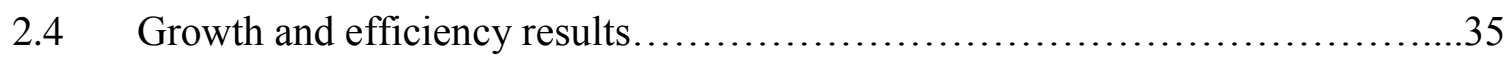

2.5 Energy calculation results for net energy and effective energy.................36

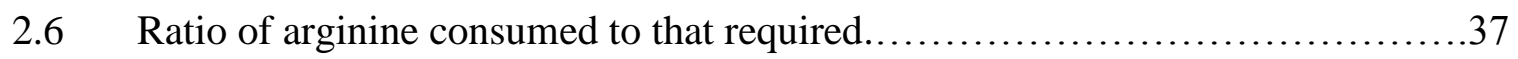

2.7 Manure excretion results...................................................

3.1 Ingredients and chemical composition of continuous culture diets..............50

Continuous culture results............................................ 51

Continuous culture volatile fatty acid results..............................52

Continuous culture digestibility results..................................53

4.1 First phase diet composition.........................................63

4.2 Second phase diet composition......................................64

4.3 Third phase diet composition........................................65

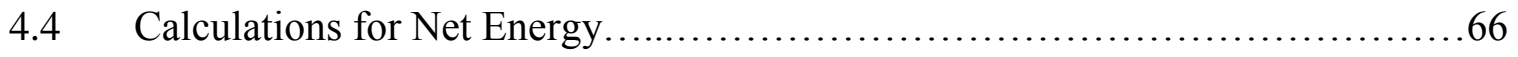

4.5 Calculations for Effective Energy....................................67

4.6 Growth and efficiency results.........................................68

4.7 Carcass measurements............................................69

4.8 Energy calculation results for Net Energy and Effective Energy.................70 


\title{
FEEDLOT CATTLE RESPONSE TO RUMEN UNDEGRADABLE PROTEIN AND DIET FIBER LEVEL OF HIGH CONCENTRATE DIETS
}

\author{
Joseph Walter Golden \\ Dr. Monty S. Kerley, Dissertation Supervisor
}

\begin{abstract}
Studies were conducted to determine the effects of feeding rumen undegradable protein (RUP) on subsequent feedlot cattle performance. The first experiment was conducted to determine if growth rate and gain to feed ratio (GF) could be improved in feedlot steers by balancing the diet for absorbable amino acid requirements. It was concluded from this research that animal performance could be improved when diets were formulated to meet the absorbable amino acid requirements. The removal of roughage and optimization of rumen undegradable amino acids (RUAA) in the feedlot diet led to improved gain efficiencies that could not be accurately described by net energy (NE) system calculations. The second study was conducted to determine the neutral detergent fiber (NDF) digestibility of concentrate diets in continuous culture and to determine if reduced fiber digestibility of high concentrate diets could influence net energy (NE) calculations, hypothesizing that reduced fiber digestion in high concentrate diets would account for diet NE discrepancies. The reduced NE value of fibrous feedstuffs, if adjusted, decreased the NE system's ability to account for energy utilization by approximately $4 \%$. A final study was conducted to determine the effects of dietary arginine level on subsequent feedlot cattle performance and efficiency. Dietary arginine levels were contrasted to test the hypothesis that diets could be formulated based on
\end{abstract}


absorbable amino acid requirements. We concluded from this research that animal performance could be improved when roughage was removed and diets were formulated to meet the absorbable amino acid requirements. Dietary arginine level provided above the requirement resulted in no improvement in performance, thus providing evidence for the accuracy and reliability of empirical equations used to estimate the RUP essential amino acid flow from the rumen. 


\section{CHAPTER I}

\section{LITERATURE REVIEW}

\section{INTRODUCTION}

The efficiency by which cattle use nutrients for tissue accretion is a major determinant of profitability in the feedlot production phase. The United States Department of Agriculture has reported that feed accounts for about $60 \%$ of the total production cost for cattle (Elstien, 2002). It is therefore imperative to understand the principles of protein and energy metabolism to better develop practical feeding programs for animals to maximize their genetic potential for production. To maximize lean tissue growth and feed efficiency in ruminant animals, diets must be formulated on an amino acid basis. The level of amino acids provided in the diet should be balanced for the energy available to support growth.

The net energy (NE) system separates the requirements for energy into maintenance and weight gain functions. This separation exists because the partial efficiency of energy utilization for maintenance is higher than it is for production (Kleiber, 1975). The effective energy (EE) system likewise separates energy expenditure into the requirements for maintenance and growth, but further divides growth into energy required for protein retention and lipid retention (Emmans, 1994). The EE system more accurately assesses growth expenditures for the type of tissue accrued, believed to improve energy accounting by the animal compared to the NE system. 
Feeding ruminally degradable protein (RDP) above what is needed for maximum microbial efficiency results in inefficient use of crude protein $(\mathrm{CP})$ by the rumen microflora and, subsequently, the animal. Optimizing RDP in the diet by coordinating the RDP mass and rate of degradation with the microbial growth rate and fermentable carbohydrate mass and degradation rate can allow for removal of roughage from the diet. Microbial amino acid (MAA) flow to the small intestine can be predicted, thus allowing for the formulation of diets optimized to use rumen undegradable AA (RUAA) to meet the absorbable AA requirements of the calf.

Removal of roughage and the meeting of absorbable amino acid requirements in the feedlot diet has led to improved gain efficiencies that were not accurately described by NE system calculations (Willis and Kerley, 2004; Mueller, 2004). Therefore, the purpose of this literature review is to provide the reader with an overview of post-ruminal amino acid flow and diet formulation, net energy and effective energy system calculations, and fiber digestibility in high concentrate feedlot diets.

\section{AMINO ACIDS OVERVIEW}

The ruminant animal obtains the amino acids (AA) needed for tissue maintenance and accretion from microbial amino acids (MAA) and rumen undegradable protein (RUP) sources. It is therefore important to know the contribution of amino acids coming from each of these sources in balancing diets to meet the animal's requirement.

Microbial amino acids, as the name implies, are synthesized by rumen microbes and utilized by the animal when the microbes pass from the rumen to the small intestine. Microbial crude protein (MCP) can be the greatest contributor of AA to the ruminant 
animal, supplying from 40 to $90 \%$ of the requirement (Firkins, 1996; Koenig et al., 2000). Other estimates put the contribution of AA coming from microbial crude protein sources at 50 to $100 \%$ of requirement (NRC, 2000).

Rumen microbes can be classified as cellulolytic or amylolytic degraders. Cellulolytic bacteria degrade structural or fibrous carbohydrates, whereas, amylolytic bacteria degrade starch or nonstructural carbohydrates (NSC). In the ruminant animal, rumen microbes ferment ingested carbohydrates and produce ATP which in turn provides energy for further microbial growth. Volatile fatty acids (VFAs) are also created in the fermentation process providing an energy source to the animal upon absorption.

Cellulolytic and Amylolytic bacteria also require nitrogen $(\mathrm{N})$ to synthesize MAA. Cellulolytic bacteria can utilize ammonia, whereas amylolytic bacteria can use peptides and ammonia as N sources (Russell et al., 1992).

Microbial amino acids can provide varying levels of the animal's amino acid requirement. The level upon which the animal's AA requirement is met is dependent upon the animal's physiological state. Microbial protein can meet the animal's AA requirement for maintenance as well as slow rates of growth; however, higher rates of gain require additional AA from RUP (NRC, 2000). Rumen undegradable protein can be defined as the fraction of the feedstuff protein that passes from the rumen to the small intestine undigested by the rumen microbial population (NRC, 2000). The AA profile as well as the RUP fraction of protein varies greatly and is dependent upon the feedstuff protein source. Ideally, the AA profile of a feedstuff would compliment the AA profile of MCP by supplying AA that are limiting growth (Santos et al., 1998). Being able to 
meet amino acid needs without exceeding them would provide for the most efficient form of gain.

The ability to accurately predict the flow of MAA from the rumen is necessary to optimally formulate diets with supplemental RUP sources to supply the limiting essential amino acids (EAA). The RUP value of a feedstuff is not constant and is dependent upon feedstuff processing and particle size, rumen $\mathrm{pH}$, dilution rate, and carbohydrate availability (Owens and Isaacson, 1977; NRC, 2000).

\section{MICROBIAL EFFICIENCY}

Microbial efficiency (MOEFF) is the gram of microbial (bacterial) N produced per kilogram of organic matter truly fermented (OMTF) (Demeyer and Van Nevel, 1986). Therefore, the yield of microbial crude protein (MCP) or microbial amino acids (MAA) can simply be calculated by multiplying MOEFF by the amount of OMTF in the rumen. Microbial efficiency generally increases with an increase in organic matter intake (OMI). Microbial efficiency is generally higher with forage based diets than with concentrate based diets due to lower maintenance energy costs for fiber-degrading bacteria. The lower maintenance energy cost of fiber-degrading bacteria results in a higher percent of the generated ATP being available for growth (Church, 1988).

Many researchers have indicated multiple factors affecting MOEFF and include substrate availability, maintenance energy cost, energetic uncoupling, rumen $\mathrm{pH}$, and $\mathrm{N}$ recycling in the rumen (Kennedy et al., 1976; Hespell and Bryant, 1979; Demeyer and Van Nevel, 1986; NRC, 2000). However, most of these studies have failed to recognize 
the effect of dilution rate (DR) on the above factors and on MOEFF. Meng et al. (1999) showed MOEFF to be a function of the solid dilution rate (SDR) out of the rumen.

\section{DILUTION RATE}

Dilution rate is the percentage of the rumen volume that passes from the rumen in an hour and is partitioned between solids and liquids. Liquids generally have a faster DR from the rumen when compared to solids (Church, 1988). The majority of the rumen microbes are attached to feed particles and pass from the rumen with the solid fraction making solid dilution rate more critical in determining an accurate MOEFF (Firkins, 1996).

Solid DR affects MOEFF by determining the microbial growth rate, microbial maintenance requirements, energy availability, as well as $\mathrm{N}$ recycling within the rumen. The microbial growth rate (cell division minus cell lysis rate) is usually represented by the DR because in a steady state environment the growth rate is equal to the DR. The maximum microbial yield would theoretically occur at a DR similar to the microbial division rate (Meng et al., 1999). The growth curve of a microbe consists of an exponential or log phase, a stationary phase, and a death phase. The exponential or log phase occurs when microbes are growing and dividing at the maximal rate possible given the environmental conditions and substrate/nutrient availability (Prescott et al., 1996). The stationary growth phase occurs when microbial cell population decreases and the growth curve becomes horizontal (Prescott et al., 1996). An increase in microbial crude protein would be minimal during the stationary phase as energy would be utilized for 
maintenance of the current microbial population. The death phase occurs when microbes lyse and the microbial $\mathrm{N}$ of the microbes are degraded to ammonia and recycled within the rumen. Solid DR affects MOEFF by influencing the amount of bacteria in the growth phase. An increase in the division rate would allow more microbes to flow from the rumen while in the growth phase instead of the less efficient stationary and death phases. Increasing bacteria flow from the rumen while in the growth phase increases MOEFF by reducing maintenance costs, reducing energetic uncoupling within the microbes, and reducing $\mathrm{N}$ recycling within the rumen (Firkins, 1996; McAllister et al., 1994).

\section{Substrate availability and ATP yield}

Energy availability in the form of ATP and substrate availability (ammonia-N, peptides, and carbohydrates) have an effect on MOEFF because amount of OMTF is the denominator of the MOEFF equation. Microbial protein synthesis requires energy in the form of ATP and a nitrogen source. A shortage of fermentable carbohydrate or incomplete fermentation of carbohydrates in the rumen would result in a decrease in the maximum yield of ATP thereby limiting MCP synthesis that could occur. A shortage of either ammonia-N or peptides could limit MCP synthesis and yield. Limiting microbial growth decreases microbial cell yield and increases microbial maintenance requirements because of increased time spent in the stationary growth phase, increased cell turnover and increased energetic uncoupling (Hespell and Bryant, 1979).

Dilution rate influences substrate ATP yield by influencing the amount of time that a feedstuff is present in the rumen for fermentation. The Cornell Net Carbohydrate and Protein System (CNCPS) uses solid dilution rate (SDR) and the relative rates of degradation of a feedstuff to determine the amount of carbohydrate and $\mathrm{N}$ that is 
fermented in the rumen (Sniffen el al., 1992). The CNCPS model sets the relative rates of degradation for a feedstuff as constants leaving the SDR to determine the length of time the feedstuff remains in the rumen and ultimately the amount of available carbohydrate and $\mathrm{N}$ available for microbial growth. Meng et al. (1999) reported that as fractional DR in a mixed rumen-bacteria single-flow continuous culture system increased from 0.025 to $0.20 / \mathrm{h}$, there was a quadratic effect for DM and organic matter (OM) digestibilities for a fibrous carbohydrate (FC) diet with the highest digestibilities occurring at a DR of $0.075 / \mathrm{h}$. There was also an inverse linear effect on DM and OM digestibilities of a non-fibrous carbohydrate (NFC) and a protein-based diet as DR increased. In another study utilizing continuous cultures, volatile fatty acid (VFA) concentrations increased, DM digestibility increases and acid detergent fiber (ADF) digestibility increased as SDR decreased (Hoover et al., 1982). As SDR decreased, there was a more extensive degradation of carbohydrates in the rumen, resulting in more energy for microbial growth and MCP synthesis. Crawford et al. (1980) demonstrated a decreased SDR resulted in an increase in $\mathrm{N}$ to the rumen. Solid dilution rate has a major influence on the amount of energy and $\mathrm{N}$ yielded from a feedstuff.

\section{DILUTION RATE IMPACTS ON MICROBIAL EFFICIENCY}

Meng et al. (1999) using a mixed rumen bacteria single-flow continuous culture system set at increasing DR, was able to mathematically demonstrate that MOEFF was dependent on DR. A fibrous carbohydrate (FC), NFC, and protein based diet was fed to continuous cultures at increasing DR to determine MOEFF for the FC, NFC and protein 
degrading bacteria in the rumen. As the fractional DR increased for each diet the MOEFF increased quadratically. Multiple studies indicate that increasing liquid dilution rate (LDR) and SDR improves MOEFF (Kennedy et al., 1976; Kennedy and Milligan, 1978; Firkins et al., 1986; Meng et al., 1999). Sniffen and Robinson (1987) clarify the effects of SDR and LDR on MOEFF by stating that microbial yield reflects more closely with particulate passage rate as there is a larger, more active microbial fraction associated with it than the liquid phase. There is little evidence that microbial yield can be increased in vivo by stimulating LDR alone (Sniffen and Robinson, 1987). Crawford et al. (1980), further supports this statement by demonstrating that SDR was more important in determing MOEFF than LDR.

\section{DETERMINING DILUTION RATE}

Dilution rate is the percentage of the rumen volume that passes from the rumen in an hour and is partitioned between solids and liquids. The factors that determine DR in ruminant animals are not fully understood. Variables suggested to affect solid DR are intake, diet type, particle size, number of meals consumed per day, hormones, regulations of digesta flow post ruminal, and animal to animal variation (Firkins et al., 1998).

Multiple studies have concluded that as intake levels increased the resulting LDR and SDR increased as well (Firkins et al., 1986; Evans, 1981; Zinn and Owens, 1983). Ludden and Kerley (1997) concluded however, that beef steers fed a diet at four different levels of energy intake had no difference in SDR as feed intake increased. 
The type of diet fed to a ruminant also affects SDR as high forage diets have longer retention times in the rumen than low forage higher concentrate diets (Demeyer and Van Nevel, 1986). Cereal grain particle size also affects SDR, as larger particles need to be digested and reduced in size to pass from the rumen. Ground or pelleted diets have higher SDR due to their smaller particle size (Demeyer and Van Nevel, 1986; Firkins et al., 1998). Particle size of a diet and the type of diet (forage vs. concentrate) affects SDR of a ruminant animal.

The number of meals an animal consumes may influence SDR as there is evidence that frequent feeding of mixed diets may slow passage rates of particles after feeding compared with infrequent feeding, thus decreasing MOEFF of frequently fed ruminants (Firkins et al., 1992). If SDR is decreased after a meal then the resulting decreased in MOEFF would agree with previous research regarding SDR affecting MOEFF (Kennedy et al., 1976; Kennedy and Milligan, 1978; Hoover et al., 1982; Demeyer and Van Neval, 1986).

\section{NET ENERGY AND EFFECTIVE ENERGY SYSTEMS}

Successful management of an animal feeding program requires a knowledge and understanding of the animal's maintenance requirements. Gross energy (GE) or the heat of combustion is the energy released as heat when an organic substance is completely oxidized to carbon dioxide and water. Gross energy, however, provides little information concerning the availability of that energy to the animal, and is of little use when assessing the value of a feedstuff as an energy source. The gross energy of a feedstuff minus the 
energy lost in the fecal output is defined as the digestible energy (DE) of the feedstuff. Though the DE value of a feedstuff gives a more accurate description of available energy, it fails to take into account the remaining losses of energy associated with digestion and metabolism of food, and as a result overestimates the value of high-fiber feedstuffs relative to low-fiber feedstuffs. The metabolizable energy (ME) of a feedstuff is determined by deducting the energy content of the feces, urine, and gas from the gross energy. The ME content of a feedstuff is an estimate of the energy that is potentially available to the animal. The net energy (NE) content of a feedstuff is a further descriptor of available energy and is determined by subtracting the heat increment or heat production from ME. The heat increment is the quantity of energy that must be furnished to keep the animal in energy equilibrium. The energy left after accounting for fecal, urinary, gas, and heat production losses represents the energy available for gain or the retained energy (RE).

Kleiber, (1975) concluded that the partial efficiency of energy utilization for maintenance is higher than it is for production. The net energy of a feed will then vary with the level of feeding, being higher at low levels of intake and decreasing as feed intake increases. The net energy system outlined by Lofgreen and Garrett (1968) takes into account the differing efficiency of utilization values for maintenance and growth and assigns separate net energy values for the differing physiological functions. Research has concluded that from maintenance to ad libitum feed consumption, the partial net energy of a feed used for weight gain does not significantly differ from linearity, which means that the partial net energy of a feed when utilized for weight gain above maintenance can be considered to be constant (Lofgreen et al., 1963; Garrett et al., 1964). The partial net 
energy for maintenance of that quantity of feed needed to maintain energy equilibrium is equal to the heat production of the fasting animal.

In order to measure the net energy for maintenance $\left(\mathrm{NE}_{\mathrm{m}}\right)$ requirement it is necessary to know the heat production of the fasting animal since this quantity of net energy must be furnished to keep the animal in energy equilibrium (Lofgreen and Garrett, 1968). It is possible to indirectly measure heat production at zero feed intake by subtracting the energy retained in the animal from the ME intake. The ME content can be found with relative ease, by deducting the fecal, urinary, and gas energy from the gross energy. The energy being retained is more complicated to measure and is determined by comparative slaughter techniques.

\section{Determination of $N E_{m}$ Requirements}

In fed animals, heat production is made up of basal metabolism, heat increment, and heat produced by activity. At zero feed intake, however, heat increment is zero and the components of heat production are basal metabolism and heat of activity which can be considered to be equal to the net energy required for maintenance or $\mathrm{NE}_{\mathrm{m}}$ (Lofgreen and Garrett, 1968). If heat production is measured at various levels of feeding it is possible to estimate heat production at zero feed intake by extrapolation.

Lofgreen and Garrett (1968) in the development of the net energy system used data from five comparative slaughter trials to obtain an estimate of heat production at zero feed intake and thus an estimate of the $\mathrm{NE}_{\mathrm{m}}$ requirements. The studies involved feeder cattle varying in weight from approximately 230 to $300 \mathrm{~kg}$. The diets used varied from 2 to $100 \%$ roughage and were fed at two or three levels of intake from maintenance to ad libitum. In each trial, energy retention was measured by the comparative slaughter 
technique and heat production calculated by deducting the energy retained from the metabolizable energy intake. In describing the relationship between daily ME intake $\left(\mathrm{kcal} / \mathrm{Weight} \mathrm{f}^{0.75}\right)$ and the daily heat produced a logarithmic equation was used since extrapolation to zero energy intake results in a more realistic estimate of fasting heat production. Over the range from maintenance to ad libitum intake, the relationship did not differ from linearity and thus the equation describing this relationship was found to be:

\section{Log heat production $=1.8851+0.00166(\mathrm{ME})$}

where heat production and ME are in kcal per Weight ${ }^{0.75} \mathrm{~kg}$. The log of the heat produced by the fasting animal was found to be equal to $1.8851 \pm 0.0293$. The antilogs of these two limits were found to be 72 and 82 , which indicated that the heat production of fasting beef cattle was probably between 72 and $82 \mathrm{kcal}$ per Weight ${ }^{0.75} \mathrm{~kg}$ (the mean value being $77 \mathrm{kcal})$. The $\mathrm{NE}_{\mathrm{m}}$ requirement of beef cattle was found to be:

$$
\mathrm{NE}_{\mathrm{m}}=77(\text { Weight })^{0.75}
$$

where $\mathrm{NE}_{\mathrm{m}}$ is in kcal per day and weight is in kilograms. This value has been modified since the original publication and the $\mathrm{W}$ or the weight is now the empty body weight of the animal (body weight $* 0.04)$.

\section{Determination of the $N E_{m}$ Values of the Ration}

In determining the $\mathrm{NE}_{\mathrm{m}}$ value of the ration, the quantity of feed intake per unit of weight $^{0.75}$ required to maintain the animal in energy equilibrium will have a $\mathrm{NE}_{\mathrm{m}}$ equal to the heat produced at no feed intake or $77 \mathrm{kcal}$. The feed intake required to maintain energy equilibrium can be measured rather simply from the relationship of heat produced to metabolizable energy intake. Feeding a diet at ad libitum intake and measuring the 
heat production at that level supplies one point in a regression line and using the heat produced at fasting as the second point can establish a regression line of heat production on metabolizable energy intake. The regression equation describing this relationship is:

\section{Log heat production $=1.8865+0.00175(\mathrm{ME})$}

where heat production and ME are in kcal per Weight ${ }^{0.75} \mathrm{~kg}$. From this relationship it was determined that energy equilibrium is achieved at an intake of $131 \mathrm{kcal}$ of ME per weight $^{0.75} \mathrm{~kg}$ since at this level of intake heat production also equals $131 \mathrm{kcal}$. From this relationship, $\mathrm{NE}_{\mathrm{m}}$ values of varying feeds can be determined. For example, at a metabolizable energy content of $1.50 \mathrm{kcal}$ per gram of feed, it would require 87.33 grams of feed to furnish $131 \mathrm{kcal}$ of ME, and thus energy equilibrium could be maintained on this feed on an intake of 87.33 grams of this feed per weight ${ }^{0.75} \mathrm{~kg}$. This quantity of feed has an $\mathrm{NE}_{\mathrm{m}}$ equal to the heat production at fasting or $77 \mathrm{kcal}$. The $\mathrm{NE}_{\mathrm{m}}$ of this feed is therefore 77 / 87.33 or 0.88 megacal per $\mathrm{kg}$.

\section{Determination of $N E_{g}$ Requirements}

The $\mathrm{NE}_{\mathrm{g}}$ requirement for weight gain is simply the energy deposited in the gain. Lofgreen and Garrett (1968) in the development of the $\mathrm{NE}_{\mathrm{g}}$ requirements used steers and heifers fed the same diets at different levels to measure energy retention. To determine if the energy concentration in the weight gain changed as the rate of gain increases the data was fitted to the equation:

$$
\mathbf{Y}=\mathbf{a} \mathbf{X}^{\mathbf{b}}
$$

where $\mathrm{Y}$ is the energy gain, $\mathrm{X}$ is the empty weight gain, and a and $\mathrm{b}$ are constants from the data. The exponent $\mathrm{b}$ represents the ratio of the specific rates of increase of energy gain and weight gain. By doing this it was found that the energy concentration of the 
weight gain increased as the rate of gain increased and that the increase was more rapid in heifers. Both findings are expected. The next step in this process was to eliminate the effect of body size on energy concentration of weight gain. To do this the relationship between energy gain and empty weight gain was determined. It was found that for any size animal that the energy stored in the weight gain or the $\mathrm{NE}_{\mathrm{g}}$ requirement could be expressed by the equations:

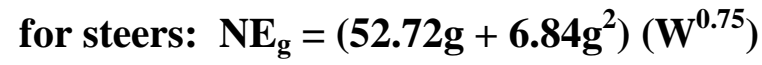

$$
\begin{aligned}
& \text { for heifers: } \mathrm{NE}_{\mathrm{g}}=\left(\mathbf{5 6 . 0 3 g}+\mathbf{1 2 . 6 5 \mathrm { g } ^ { 2 }}\right)\left(\mathrm{W}^{\mathbf{0 . 7 5}}\right)
\end{aligned}
$$

where $\mathrm{NE}_{\mathrm{g}}$ is in kcal, $\mathrm{g}$ is daily gain in kilograms, and $\mathrm{W}$ is bodyweight in kilograms. Determination of $N E_{g}$ Values of the Ration

The $\mathrm{NE}_{\mathrm{g}}$ value of a feed is equal to the energy deposited in the bodyweight gain brought about by feeding the particular feed in question. This has normally been determined by feeding the experimental diet at two levels and measuring the energy deposition brought about by the increase in feed intake between the two levels. Any two levels of feeding above maintenance can be used in a difference trial but a large difference will result in a more accurate estimate of the $\mathrm{NE}_{\mathrm{g}}$ value of the ration. The relationship of feed required to maintain energy equilibrium to the NEg concentration of the feed can be expressed by the equation:

$$
Y=2.29-0.0254 X
$$

Where $\mathrm{Y}$ equals the $\mathrm{NE}_{\mathrm{g}}$ value of the feed and $\mathrm{X}$ equals the feed intake at energy equilibrium. 


\section{ASSESSMENT OF ENERGY EXPENDITURE BY NET ENERGY AND EFFECTIVE ENERGY SYSTEMS}

The net energy (NE) system separates the requirements for energy into maintenance and weight gain functions. This separation exists because the partial efficiency of energy utilization for maintenance is higher than it is for production (Kleiber, 1975). The effective energy (EE) system is based upon calorimeter measurements, which gives information of energy flows for short time periods, measures instantaneous rates, and minimizes differences in maintenance because the change in the state of the animal is small. The EE system further separates energy expenditure into the energy required for maintenance, the energy required for protein retention, and the energy required for lipid retention, thus further minimizing errors. These EE requirements are based on body weight and average daily gain (ADG) of the animal. The EE system assesses growth expenditures for the type of tissue accrued, believed to improve energy accounting by the animal compared to the NE system.

Garrett et al. (1959) concluded that fat contains $9.367 \mathrm{kcal}$ of energy per gram and that nonfat organic matter contained an average of $5.686 \mathrm{kcal}$ of energy per gram. In the way that NEg values of rations are calculated it is reasonable to expect that errors will occur if the diets being fed are not balanced. Based on the fact that fat contains much more energy per gram than protein and the way in which NEg values are calculated, I've concluded that it is much easier to recognize that the energetic efficiencies of maintenance, lipid retention and protein retention are different than to get involved in trying to collapse these functions into one measure called NE. 


\section{NET ENERGY AND EFFECTIVE ENERGY SUMMARY}

Research conducted in our laboratory has allowed for the removal of roughage from the feedlot diet and optimization of absorbable amino acid supply relative to requirement. The feeding of optimized diets, however, has resulted in feed conversion ratios that are greater than biologically possible based on the assumptions of the net energy system. In work done in our lab (Golden and Kerley, 2005; Golden and Kerley, 2006) the results from a feeding trial were analyzed to determine which energy system could more accurately assess energy expenditure for calculated maintenance, protein retention, and lipid retention functions. The study concluded that by using the net energy equations approximately $63 \%$ of the energy consumed to that actually required could be described but that approximately $90 \%$ of the energy consumed to that actually required was described when using effective energy calculations.

Net energy system calculations (Table 1.1) were taken from the NRC (2000), whereas effective energy system calculations (Table 1.2) were taken from Emmans (1994).

\section{FIBER DIGESTIBILITY}

\section{Nonstructural Carbohydrates}

Sugars, starches, organic acids, and other reserve carbohydrates such as fructans make up the nonstructural carbohydrates (NSC) fraction and are major sources of energy for ruminants. Nonstructural carbohydrates are highly digestible and are usually added in 
high quantities to ruminant feeding programs to meet the energy demands of the animal. Ruminal fermentation of NSC varies greatly with type of feed and conservation and processing method.

The optimal concentration of NSC in diets for ruminant animals is not well defined but alteration of dietary NSC influences ruminal fermentation patterns and total tract digestion of fiber. Optimal concentration of NSC in ruminant diets is related to: 1) the effects of rapidly degradable starch on ruminal digestion of fiber, which can decrease the differences between diets relative to total carbohydrate digestion; 2) the amount of NSC that replaces NDF in the diet, as this can affect volatile fatty acid production, rumination, and saliva production; 3) site of starch digestion; 4) dry matter intake (DMI) and physiologic state of the animal; and 5) conservation and processing methods used to alter rate and extent of NSC digestion.

\section{Structural Carbohydrates}

Crude fiber, acid detergent fiber, and neutral detergent fiber are the most common measures of fiber used for routine feed analysis, but none of these fractions are chemically uniform. Neutral detergent fiber measures most of the structural components in plant cells including cellulose, hemicellulose, and lignin. Acid detergent fiber does not include hemicelluloses, and crude fiber does not quantitatively recover hemicelluloses and lignin. Neutral detergent fiber is the method that best separates structural from nonstructural carbohydrates in plants, and NDF measures most of the chemical compounds generally considered to comprise fiber. Within a specific feedstuff, concentrations of NDF, ADF, and crude fiber are highly correlated, but for mixed diets 
that contain different fiber sources, the correlations among the different measures of fiber are lower.

On average NDF is less digestible than nonfiber carbohydrates; therefore, the concentration of NDF in feeds or diets is negatively correlated with energy concentration. The chemical composition of the NDF fraction, or proportion of cellulose, hemicelluloses and lignin, affects the digestibility of NDF. Therefore, feeds or diets with similar NDF concentrations will not necessarily have similar net energy of gain (NEg) concentrations.

\section{NEUTRAL DETERGENT FIBER DIGESTIBILITY AND EFFECT ON INTAKE}

It is well established that rumination and mastication are associated with the processes of feed intake as well as their limitations (Schalk and Amadon, 1928; Balch, 1952; 1971; Pearce and Moir, 1964; Troelsen and Bigsby, 1964; Weston and Hogan, 1967). Variations in energy, protein and other nutrients of poor quality forages confounds investigations associated with rumination.

Intake by beef cattle fed high-concentrate, grain-based diets is likely controlled primarily by metabolic factors and not limited by bulk fill. Nonetheless, small increases of $5 \%$ of dry matter or less in the concentration of bulky roughage and changing from less fibrous to more fibrous sources of roughage typically increase dry matter intake by feedlot cattle (Galyean and Defoor, 2003). Arelovich et al. 2008 concluded that DMI expressed either as a percentage of body weight or in kilograms per day of dry matter per animal were positively related to increasing dietary NDF concentration. Galyean and Defoor (2003) reported that NDF supplied by roughage was highly related to DMI in 
feedlot cattle. Arelovich et al. (2008) suggested that total dietary NDF concentration in beef feedlot diets has a similar relationship to DMI as does NDF supplied by the roughage portion of the diet. Arelovich et al. (2008) further concluded that NEg intake ( $\mathrm{kcal} / \mathrm{kg}$ of $\mathrm{BW}^{0.75}$ ) of beef feedlot cattle was highly related to dietary NDF concentration, but total dietary NDF did not account for variation in intake of NEg per unit of DMI. Thus at low dietary NDF supply, as is the case in beef feedlot rations, DMI is most likely regulated by physiological mechanisms (Forbes, 2000) rather than by critical distention of the reticulo-rumen.

Reasons for increased dry matter intake with changes in roughage level and source are not fully understood. Energy dilution effects caused by added dietary fiber might be responsible for altered dry matter intake, but the quantity of dietary net energy for gain provided by roughage shows little relationship to changes in dry matter intake with roughage source and level (Galyean and Defoor, 2003).

\section{IMPACT OF RUMEN pH ON FIBER DIGESTION}

Low ruminal $\mathrm{pH}$ depresses digestion of forage fiber, but the effects of low $\mathrm{pH}$ on specific digestion kinetics (lag time and rate and extent of NDF digestibility) have varied among studies (Hoover, 1986; Russell et al., 1992). Dilution of starch with non-forage fiber sources may (Sarwar, et al., 1992) or may not (Cunningham et al., 1993) increase ruminal $\mathrm{pH}$. If ruminal $\mathrm{pH}$ is increased, there may be increased ruminal NDF digestion of all fiber sources, which are prone to negative associative effects (Tyrell and Moe). Tyrell and Moe (1975) previously described negative associative effects. 
Ruminal $\mathrm{pH}$ affects fiber digestion through its influence on the specific growth rates of cellulolytic bacteria. Growth of cellulolytic bacteria is optimal at ruminal $\mathrm{pH}$ of greater than 6.5. Cellulolytic bacteria do not grow at ruminal $\mathrm{pH}$ below 6.0. This toxicity is due apparently to the inability of cellulolytic bacteria to regulate intracellular anion concentrations at lower ruminal $\mathrm{pH}$ (Russell and Wilson, 1996). In addition to specific growth rates of cellulolytic bacteria, the availability or accessibility of substrate to the cellulolytic process is also an important limitation to the rate of fiber digestion (Russell and Wilson, 1996).

\section{CONCLUSION}

In reviewing the literature regarding post-ruminal amino acid flow and diet formulation, net energy and effective energy system calculations and fiber digestibility there is a need and a means to improving feedlot feeding system efficiencies. The removal of roughage and the optimization of amino acid flow in feedlot diets can lead to improved gain efficiencies. Fiber digestibility can be negatively impacted by feeding high concentrate diets. Net energy system calculations were reviewed and found to be inadequate at accurately assessing energy expenditure for calculated maintenance, protein retention, and lipid retention functions. The assumptions of the effective energy system were more accurate when compared to the net energy system. More research is

warranted to determine if continued improvements in feedlot cattle response to RUP will be accurately described by the effective energy system. 
Table 1.1. Calculations for Net Energy

\begin{tabular}{ll}
\hline Term & Calculation \\
\hline NEm of Diet & Based on NEm values of feed \\
NEg of Diet & Based on NEg values of feed \\
Measurement day (MD) weight & Based on Wt at measurement \\
Shrunk body weight (SBW) & MDwt-(MDw*0.04) \\
Average Daily Gain (ADG) & Based on actual animal gain \\
Average Intake & Based on actual animal intake \\
NEm requirement & $0.077^{*}\left(\mathrm{SBW}^{\wedge} 0.75\right)$ \\
Feed to meet NEm & NEm requirement/NEm of diet \\
Available feed for NEg & Average intake-feed to meet NEm \\
Shrunk weight gain (SWG) & ADG-(ADG*0.04) \\
NEg required & (SWG/(13.91*SBW^-0.6837)) \\
NEg available & Available feed for NEg*NEg of diet \\
NE consumed to NE required & NEg available/NEg required \\
\hline
\end{tabular}


Table 1.2. Calculations for Effective Energy

\begin{tabular}{|c|c|}
\hline Term & Calculation \\
\hline Metabolizable Energy (ME) & Based on ME values of feed \\
\hline Crude Protein $(\mathrm{CP})$ & Based on CP level of feed \\
\hline $\begin{array}{l}\text { Empty Body Weight } 1 \text { (EBW1) } \\
\text { for measurement day (MD) }\end{array}$ & MDwt*0.891 \\
\hline Empty Body Weight 2 (EBW2) & $(\mathrm{MDwt}-\mathrm{ADG})^{*} 0.891$ \\
\hline Effective Energy (EE) & $\left(\left(1.15^{*} \mathrm{ME}\right)-3.84-((4.67 *(\mathrm{CP} * 0.8 / 100)))\right.$ \\
\hline $\mathrm{EE} /$ day & EE*Average intake \\
\hline Maintenance Heat (MH) & $\left(\mathrm{EBW} 2^{\wedge} 0.75\right) * 420 \mathrm{KJ}$ \\
\hline Body Protein for EBW1 & $\left(-2.418+\left(0.235^{*} \mathrm{EBW} 1\right)-\left(0.00013^{*} \mathrm{EBW} 1^{\wedge} 2\right)\right)$ \\
\hline Body Protein for EBW2 & $\left(-2.418+\left(0.235^{*} \mathrm{EBW} 2\right)-\left(0.00013 * \mathrm{EBW} 2^{\wedge} 2\right)\right)$ \\
\hline Protein Retention (PR) & Body protein from EBW2 - Body protein EBW1 \\
\hline Body Lipid for EBW1 & $\left(-0.61+(0.037 * \mathrm{EBW} 1)+\left(0.00054^{*} \mathrm{EBW} 1 \wedge 2\right)\right)$ \\
\hline Body Lipid for EBW2 & $\left(-0.61+(0.037 *\right.$ EBW2 $\left.)+\left(0.00054 * \mathrm{EBW}^{\wedge}{ }^{\wedge} 2\right)\right)$ \\
\hline Lipid Retention (LR) & Body lipid from EBW2 - Body lipid EBW1 \\
\hline EE requirement (EERQ) & $(\mathrm{MH}+(\mathrm{PR} * 50)+(\mathrm{LR} * 56)) / 1000$ \\
\hline Ratio of EE to EERQ & EE/EERQ \\
\hline
\end{tabular}




\title{
CHAPTER II
}

\section{BALANCING DIETS TO MEET THE ANIMAL'S REQUIREMENT FOR ABSORBABLE AMINO ACIDS}

\begin{abstract}
A study was conducted to determine if growth rate and gain to feed ratio (GF) could be improved in feedlot steers by balancing the diet for absorbable amino acid requirements. The ruminally degradable protein (RDP) in the diet met, but did not exceed predicted degradable nitrogen required to maximize microbial efficiency. Three protein sources, bloodmeal (BM), fishmeal (FM), and AminoPlus® (AP) were contrasted to test the hypothesis that diets could be formulated, based on absorbable amino acid requirements. The BM, FM, and AP diets were whole corn based and contained a vitamin-mineral premix with Rumensin and Tylan. The control diet (14\% CP; SBM) was whole corn based with soybean meal, hay (10\%), and a vitamin-mineral premix with Rumensin and Tylan. The BM, FM, and AP diets were formulated to achieve an average daily gain (ADG) of $2.05 \mathrm{~kg}$ during phase one (P1; Day 0 to 84 ) and $1.70 \mathrm{~kg}$ for phase two (P2; Day 84 to finish). Diets were optimized for RDP and microbial crude protein estimates were calculated using empirical equations previously used by Mueller (2004) to estimate the rumen undegradable protein (RUP) essential amino acid (EAA) flow from the rumen. Amino acid requirements of feedlot steers were based upon the original CNCPS. Starting and ending weights did not differ $(\mathrm{P}>0.05)$ between treatment groups.
\end{abstract}


The ADG did not differ $(\mathrm{P}>0.05)$ during P1 for AP, BM, FM, and SBM groups. Dry matter intake (DMI) during $\mathrm{P} 1$ differed $(\mathrm{P}<0.05)$ between groups $(6.39,7.05,6.84$, and $7.00 \mathrm{~kg}$, respectfully) with cattle fed FM consuming the least amount of feed per day when compared to AP, BM, and SBM diets. The GF differed $(\mathrm{P}<0.05)$ during $\mathrm{P} 1$ for AP, BM, FM, and SBM groups with BM cattle having a greater GF ratio when compared to SBM cattle. During the second phase of feedlot production ADG differed $(\mathrm{P}<0.05)$ between groups with the AP group having a lower ADG than BM, FM, and SBM groups. There was no difference $(\mathrm{P}>0.05)$ in GF for AP, BM, FM, and SBM groups. Dry matter intake during $\mathrm{P} 2$ differed $(\mathrm{P}<0.05)$ between groups $(9.23,8.34,8.10$, and $7.90 \mathrm{~kg}$, respectfully) with SBM cattle having the largest DMI when compared to AP, BM, and FM cattle. Average P1 pen wet manure weight differed $(\mathrm{P}<0.05)$ between groups (271, 173,117 , and $112 \mathrm{~kg}$, respectfully) with SBM cattle excreting more manure than AP, BM and FM groups. Average pen wet manure weight during $\mathrm{P} 2$ differed $(\mathrm{P}<0.05)$ for AP, BM, FM, and SBM groups with AP, BM, and FM cattle excreting less manure than SBM cattle $(157,162,151$, and $268 \mathrm{~kg}$, respectfully). We concluded from this research that animal performance can be improved when roughage is removed and diets are formulated to meet the absorbable amino acid requirements.

\section{INTRODUCTION}

The efficiency by which cattle use nutrients for tissue accretion is a major determinant of profitability in the feedlot production phase. It is therefore imperative to 
understand the principles of protein and energy metabolism to better develop practical feeding programs for animals to maximize their genetic potential for production.

The net energy (NE) system separates the requirements for energy into maintenance and weight gain functions. This separation exists because the partial efficiency of energy utilization for maintenance is higher than it is for production (Kleiber, 1975).

The effective energy (EE) system likewise separates energy expenditure into the requirements for maintenance and growth, but further divides growth into energy required for protein retention and lipid retention (Emmans, 1994). The EE system more accurately assesses growth expenditures for the type of tissue accrued, believed to improve energy accounting by the animal compared to the NE system.

Feeding ruminally degradable protein (RDP) above what is needed for maximum microbial efficiency results in inefficient use of crude protein (CP) by the rumen microflora and, subsequently, the animal. Research conducted in our laboratory led to the conclusion that optimizing RDP in the diet (coordinating the RDP mass and rate of degradation with the microbial growth rate and fermentable carbohydrate mass and degradation rate) allowed for removal of roughage from the diet. It was also found that microbial amino acid (AA) flow to the small intestine could be predicted, thus allowing for the formulation of diets optimized to use rumen undegradable AA (RUAA) to meet the absorbable AA requirements of the calf.

The removal of roughage and the optimizing of RUAA in the diet reduced waste volume of excreta by approximately three-fold and greatly increased gain efficiency. The increased gain efficiency (assessed by the feed conversion ratio) measured in cattle fed 
optimized diets was greater than biologically possible based upon NE system calculations.

The objective of this experiment was to 1) verify that matching absorbable AA flow to absorbable AA requirement improved growth performance of steer calves in the feedlot; 2) determine the ability of predictive equations to match RUAA delivery from two different proteins with RUAA needs of the growing calf; 3) evaluate the accuracy of EE relative to NE equations in determining energy expenditure by calves fed diets balanced for RUAA delivery; and 4) determine the ability of optimized diets to reduce waste volume of excreta.

\section{MATERIALS AND METHODS}

There were four experimental treatments in a completely randomized design. Treatment diets consisted of a positive control (soybean meal protein, 10\% hay) and three diets without roughage and formulated to optimize RDP and RUAA (Table 2.1). The three diets differed in the source of protein (blood meal (BM), fish meal (FM), or AminoPlus (AP)).

Bloodmeal, FM, and AP diets were formulated to achieve an average daily gain (ADG) of $2.05 \mathrm{~kg}$ during phase one (P1; Days 0 to 84$)$ and $1.70 \mathrm{~kg}$ for phase two (P2; Days 84 to finish). The protein level of the two diets varied depending on the ability of the protein to deliver the most limiting RUAA. Diets consisted primarily of whole shelled corn, a pelleted protein/ground corn supplement and a vitamin-mineral premix with Rumensin and Tylan. Diets were optimized for rumen degradable protein and 
microbial crude protein estimates were calculated using empirical equations. Amino acid requirements of feedlot steers were based upon the original CNCPS.

Fifty-four Angus steers (initial weight approximately $300 \mathrm{~kg}$ ) were purchased from a recognized preconditioning program. Upon arrival to the University of Missouri Beef Farm the steers were placed on a receiving diet for 14 days. Following the receiving period, steers were weighed on two consecutive days and stratified to pens by weight. Three pens of steers (six head per pen) were assigned to each treatment. Three steers were removed from the study. Steers were weighed on single days at 21-day intervals following the initiation of the feeding trial and on two consecutive days at the termination of the trial to allow for average daily gain and feed efficiency calculations. Steers were fed once daily and had ad libitum access to water. Pen feed intake measurements were recorded.

During both phase one and phase two of the feeding trial, total waste volume of excreta was collected and measured for seven days. Pens consisted of concrete flooring with curbs to prevent manure run-off to other pens. During the sampling periods steers were eating at full-feed and there was no rainfall. Manure was sub-sampled to allow for further analysis.

Net energy requirements were calculated using animal growth data and feed energy values found in the beef National Research Council (NRC, 2000). The ratio of $\mathrm{NE}$ consumed to the NE required for the measured growth was calculated for each treatment group. Equations used to calculate NE during P1 are found in Table 2.2. Effective energy requirements were calculated using measured animal growth data and equations based on work done by Emmans (1994). The ratio of EE consumed to the EE 
required for the measured growth was calculated for each treatment group. Equations used to calculate EE during P1 are found in Table 2.3.

Statistical Analysis

Initial weight, final ending weight, average daily gain, gain to feed ratio, and treatment wet manure weight were analyzed using the general linear model of SAS (2002-2008). Pen was experimental unit. Differences between treatments were determined using Fisher's least significant difference statement of SAS (2002-2008). Significant differences were determined at the $\mathrm{P}<0.05$ level.

\section{RESULTS AND DISCUSSION}

Starting and ending weights did not differ $(\mathrm{P}>0.05)$ between treatment groups (Table 2.4). Average daily gain did not differ $(\mathrm{P}>0.05)$ during $\mathrm{P} 1$ for AP, BM, FM, and SBM groups (Table 2.4). Compared to animals of similar size, the ADG values reported in this trial were better than those reported by Barajas and Zinn (1998) and Zinn et al. (1998), in which traditional corn-based feedlot diets with roughage were fed. Average daily gain values from this study were better than those reported by Murphy and Loerch (1994) in which all-concentrate diets were fed. The ADG values from this study were similar to those reported by Mueller (2004) and Willis and Kerley (2004) where no roughage diets were fed. Dry matter intake (DMI) during $\mathrm{P} 1$ differed $(\mathrm{P}<0.05)$ between groups with cattle fed FM consuming the least amount of feed per day when compared to AP, BM, and SBM diets (Table 2.4). Feedlot studies traditional diets with roughage and using animals of similar size reported intakes of 7.2 to $9.2 \mathrm{~kg}$ (Barajas and Zinn, 1998; 
Lehmkuhler, 2001; Zinn et al. 1997; 1998), whereas feedlot studies using all-concentrate diets reported intakes of 6.1 to $9.2 \mathrm{~kg}$ (Murphy and Loerch, 1994; Mueller, 2004; Willis and Kerley, 2004).

The GF differed $(\mathrm{P}<0.05)$ during $\mathrm{P} 1$ for AP, BM, FM, and SBM groups with BM cattle having a greater GF ratio when compared to SBM cattle (Table 2.4). During the second phase of feedlot production ADG differed $(\mathrm{P}<0.05)$ with the AP group having a lower ADG than BM, FM, and SBM groups. There was no difference (P > 0.05) in GF for AP, BM, FM, and SBM groups. Dry matter intake during P2 differed (P $<0.05)$ between groups with SBM cattle having the largest DMI when compared to AP, BM, and FM cattle (Table 2.4).

Total pen manure was collected for one week during P1. Average pen wet manure weight differed $(\mathrm{P}<0.05)$ for AP, BM, FM, and SBM groups with AP, BM and FM cattle excreting less manure than SBM cattle (Table 2.7). Average pen wet manure weight during P2 differed $(\mathrm{P}<0.05)$ for AP, BM, FM, and SBM groups with AP, BM, and FM cattle excreting less manure than SBM cattle (Table 2.7).

Net energy and effective energy calculations are provided in Table 2.5. During both P1 and P2 of the feeding trial effective energy calculations were more capable of accurately assessing energy expenditure among maintenance, protein retention, and lipid retention (Table 2.5). When optimized diets were fed it is concluded that the net energy system cannot accurately predict measured growth efficiencies. Using more descriptive measures of maintenance heat expenditure, effective energy predictions would capture the FCR range expected among animals. Assessing nutritional and genetic influence on FCR should be based upon the effective energy system rather than the net energy system. 
Bloodmeal and fishmeal diets were optimized for RDP and microbial crude protein estimates were calculated using emperical equations. Diets were balanced for the rumen undegradable amino acid needs of the growing calf. The first limiting amino acid of feedlot steers fed diets consisting primarily of whole corn was found to be arginine. Based on the average growth and dry matter intake of treatment groups the ratio of arginine consumed in the diet to that required based on growth was calculated. During phase one of the feedlot production phase FM and BM diets were closer to meeting the arginine requirement of the growing steer (Table 6). During P2 of the feedlot production phase there was no difference between treatment groups to meet the arginine requirements of the feedlot steer (Table 6).

\section{CONCLUSION}

Growth and feed efficiency were improved when diets were formulated to meet the absorbable amino acid requirements of the feedlot steer. Steers fed FM and BM diets produced significantly less manure excreta when compared to the traditional SBM diet with roughage. Further research is warranted to determine the economic and environmental value of this finding.

The feeding of optimized diets led to predictive deficiencies when using the net energy system calculations. By utilizing effective energy calculations we were better able to describe the energetic expenditures among maintenance, lipid retention, and protein retention functions of the feedlot steer. Assessing nutritional and genetic influence on FCR should be based upon the effective energy system rather than the net 
energy system. By balancing diets for the rumen undegradable amino acid needs of the growing calf we were able to accurately predict the growth and amino acid needs of the feedlot steer. We concluded from this research that animal performance and feed efficiency can be improved when roughage is removed and diets are formulated to meet the absorbable amino acid requirements of the feedlot steer. 
Table 2.1. Diet Composition

\begin{tabular}{|c|c|c|c|c|c|c|c|c|}
\hline \multirow[b]{2}{*}{ Ingredients } & \multicolumn{4}{|c|}{ Phase One Diet Composition } & \multicolumn{4}{|c|}{ Phase Two Diet Composition } \\
\hline & FM & BM & AP & SBM & FM & BM & $\mathrm{AP}$ & SBM \\
\hline Whole Corn & 87.45 & 88.45 & 77.97 & 78.50 & 92.85 & 93.15 & 89.30 & 78.50 \\
\hline Fishmeal & 9.30 & --- & -- & -- & 4.30 & -- & -- & -- \\
\hline Bloodmeal & --- & 8.30 & --- & --- & --- & 4.00 & -- & --- \\
\hline Amino Plus & --- & --- & 19.00 & --- & --- & & 8.00 & --- \\
\hline Soybean meal & --- & --- & --- & 9.00 & --- & --- & --- & 9.00 \\
\hline Hay & --- & --- & -- & 10.00 & --- & --- & --- & 10.00 \\
\hline $\begin{array}{l}\text { Vit/Min } \\
\text { Premix }{ }^{1}\end{array}$ & 3.25 & 3.25 & 3.03 & 2.50 & 2.85 & 2.85 & 2.7 & 2.50 \\
\hline $\mathrm{KCl}$ & 0.70 & 0.70 & --- & --- & 0.70 & 0.70 & --- & --- \\
\hline
\end{tabular}


Table 2.2. Calculations for Net Energy

\begin{tabular}{lll}
\hline Term & Value & Calculation \\
\hline NEm of Diet & $2.07(\mathrm{Mcal} / \mathrm{kg})$ & \\
NEg of Diet & $1.41(\mathrm{Mcal} / \mathrm{kg})$ & \\
Day 84 Weight (D84wt) & $438 \mathrm{~kg}$ & \\
Shrunk body weight (SBW) & $420.5 \mathrm{~kg}$ & D84wt-(D84wt*0.04) \\
Average Daily Gain (ADG) & $1.64 \mathrm{~kg}$ & \\
Average Intake & $6.21 \mathrm{~kg}$ & \\
NEm requirement & $7.15 \mathrm{Mcal}$ & $0.077^{*}\left(\mathrm{SBW} \mathrm{N}^{\wedge} 0.75\right)$ \\
Feed to meet NEm & $3.46 \mathrm{~kg}$ & NEm requirement/NEm of diet \\
Available feed for NEg & $2.75 \mathrm{~kg}$ & Average intake-feed to meet NEm \\
Shrunk weight gain (SWG) & $1.57 \mathrm{~kg}$ & ADG-(ADG*0.04) \\
NEg required & $7.04 \mathrm{Mcal}$ & $\left(\mathrm{SWG} /\left(13.91^{*} \mathrm{SBW}{ }^{\wedge}-0.6837\right)\right)$ \\
NEg available & 3.66 & Available feed for NEg*NEg of diet \\
NE consumed to NE required & 0.52 & NEg available/NEg required \\
\hline
\end{tabular}


Table 2.3. Calculations for Effective Energy

\begin{tabular}{lll}
\hline Term & Value & Calculation \\
\hline Metabolizable Energy (ME) & $13.55 \mathrm{MJ} / \mathrm{kg}$ diet & \\
Crude Protein (CP) & 13.40 & \\
Empty Body Weight 1 (EBW1) & 391.7 & D84wt*0.891 \\
Empty Body Weight 2 (EBW2) & 390.2 & $(\mathrm{D} 84 \mathrm{wt}-\mathrm{ADG})^{*} 0.891$ \\
Effective Energy (EE) & $11.24 \mathrm{MJ} / \mathrm{kg}$ diet & $\left(\left(1.15^{*} \mathrm{ME}\right)-3.84-\left(\left(4.67^{*}(\mathrm{CP} * 0.8 / 100)\right)\right)\right.$ \\
EE/day & $69.8 \mathrm{MJ}$ & $\mathrm{EE} * \mathrm{Average}$ intake \\
Maintenance Heat (MH) & $36878 \mathrm{KJ}$ & $\left(\mathrm{EBW} 2^{\wedge} 0.75\right)^{*} 420 \mathrm{KJ}$ \\
Body Protein for EBW1 & $69.69 \mathrm{~kg}$ & $\left(-2.418+\left(0.235^{*} \mathrm{EBW} 1\right)-\left(0.00013^{*} \mathrm{EBW} 1^{\wedge} 2\right)\right)$ \\
Body Protein for EBW2 & $69.49 \mathrm{~kg}$ & $\left(-2.418+\left(0.235^{*} \mathrm{EBW} 2\right)-\left(0.00013^{*} \mathrm{EBW} 2^{\wedge} 2\right)\right)$ \\
Protein Retention (PR) & $194.85 \mathrm{grams}$ & \\
Body Lipid for EBW1 & $96.74 \mathrm{~kg}$ & $\left(-0.61+\left(0.037^{*} \mathrm{EBW} 1\right)+\left(0.00054^{*} \mathrm{EBW} 1^{\wedge} 2\right)\right)$ \\
Body Lipid for EBW2 & $96.07 \mathrm{~kg}$ & $\left(-0.61+\left(0.037^{*} \mathrm{EBW} 2\right)+\left(0.00054^{*} \mathrm{EBW} 2^{\wedge} 2\right)\right)$ \\
Lipid Retention $(\mathrm{LR})$ & $671.1 \mathrm{grams}$ & \\
EE requirement (EERQ) & $84.2 \mathrm{MJ}$ & $(\mathrm{MH}+(\mathrm{PR} * 50)+(\mathrm{LR} * 56)) / 1000$ \\
Ratio of EE to EERQ & 0.83 & EE/EERQ \\
\hline
\end{tabular}


Table 2.4. Growth and efficiency results

\begin{tabular}{lcccc}
\hline & \multicolumn{3}{c}{ Treatments } \\
\cline { 2 - 5 } Item & AP & BM & FM & SBM \\
\hline Initial Wt, kg & 300.89 & 305.06 & 302.63 & 300.72 \\
Final Wt, kg & 489.39 & 510.65 & 499.69 & 499.00 \\
ADG 0-84, kg & 1.65 & 1.79 & 1.63 & 1.61 \\
ADG 84-127, kg & $1.17^{\mathrm{b}}$ & $1.28^{\mathrm{a}, \mathrm{b}}$ & $1.40^{\mathrm{a}, \mathrm{b}}$ & $1.46^{\mathrm{a}}$ \\
ADG 0-127, kg & 1.49 & 1.62 & 1.55 & 1.56 \\
DMI 0-84, kg & $7.05^{\mathrm{a}}$ & $6.84^{\mathrm{a}}$ & $6.39^{\mathrm{b}}$ & $7.00^{\mathrm{a}}$ \\
DMI 84-127, kg & $8.34^{\mathrm{b}}$ & $8.10^{\mathrm{b}}$ & $7.90^{\mathrm{b}}$ & $9.23^{\mathrm{a}}$ \\
DMI 0-127, kg & $7.48^{\mathrm{a}, \mathrm{b}}$ & $7.27^{\mathrm{b}}$ & $6.90^{\mathrm{c}}$ & $7.76^{\mathrm{a}}$ \\
G:F 0-84 & $0.236^{\mathrm{a}, \mathrm{b}}$ & $0.263^{\mathrm{a}}$ & $0.256^{\mathrm{a}, \mathrm{b}}$ & $0.231^{\mathrm{b}}$ \\
G:F 84-127 & 0.14 & 0.15 & 0.17 & 0.15 \\
G:F 0-127 & $0.20^{\mathrm{b}}$ & $0.22^{\mathrm{a}, \mathrm{b}}$ & $0.23^{\mathrm{a}}$ & $0.20^{\mathrm{b}}$ \\
\hline
\end{tabular}

${ }^{\mathrm{a}, \mathrm{b}, \mathrm{c}}$ Means within row lacking a common superscript differ $(\mathrm{P}<0.05)$. 
Table 2.5. Energy Calculation Results for Net Energy and Effective Energy

\begin{tabular}{lllll}
\hline Diet & AP & FM & BM & SBM \\
\hline P1 NE & 0.53 & 0.52 & 0.55 & 0.66 \\
P2 NE $^{1}$ & 0.64 & 0.76 & 0.78 & 1.01 \\
P1 EE $^{2}$ & 0.70 & 0.83 & 0.83 & 0.89 \\
$\mathrm{P}^{2} \mathrm{EE}^{2}$ & 0.85 & 1.00 & 1.00 & 1.13 \\
\hline
\end{tabular}

${ }^{\mathrm{l}}$ Ratio of net energy consumed to that required.

${ }^{2}$ Ratio of effective energy consumed to that required. 
Table 2.6. Ratio of arginine consumed to that required

\begin{tabular}{lcccc}
\hline & \multicolumn{4}{c}{ Treatments } \\
\cline { 2 - 5 } Production Phase & AP & BM & FM & SBM \\
\hline Day 0-84 & 1.09 & 1.06 & 1.04 & 0.86 \\
Day 84-127 & 1.03 & 1.01 & 1.04 & 1.02 \\
\hline
\end{tabular}


Table 2.7. Manure excretion results

\begin{tabular}{lcccc}
\hline & \multicolumn{4}{c}{ Treatments } \\
\cline { 2 - 5 } Item & AP & BM & FM & SBM \\
\hline P1 Wet Manure Wt, kg & $173^{\mathrm{b}}$ & $117^{\mathrm{b}}$ & $112^{\mathrm{b}}$ & $271^{\mathrm{a}}$ \\
P1 Manure DM\%, & 34.90 & 35.97 & 39.60 & 38.70 \\
P2 Wet Manure Wt, kg & $157^{\mathrm{b}}$ & $162^{\mathrm{b}}$ & $151^{\mathrm{b}}$ & $268^{\mathrm{a}}$ \\
P2 Manure DM\% & 42.03 & 42.73 & 48.4 & 41.03 \\
\hline
\end{tabular}

${ }^{\mathrm{a}, \mathrm{b}}$ Means within row lacking a common superscript differ $(\mathrm{P}<0.05)$. 


\title{
CHAPTER III
}

\section{DIGESTIBILITY OF FIBER SOURCES IN HIGH CONCENTRATE DIETS IN}

VITRO

\begin{abstract}
The removal of roughage and optimization of rumen undegradable amino acids (RUAA) in the feedlot diet has led to improved gain efficiencies that cannot be accurately described by net energy (NE) system calculations. The objective of this study was to determine the neutral detergent fiber (NDF) digestibility of concentrate diets in continuous culture and to determine if reduced fiber digestibility of high concentrate diets could influence net energy (NE) calculations. The hypothesis was that reduced fiber digestion in high concentrate diets would account for diet NE discrepancies. A singleflow continuous culture fermentation system operating at a fractional dilution rate (DR) of 0.04 was used to determine microbial efficiency (MOEFF) and NDF digestibility. Four diets were formulated to meet the amino acid needs of a feedlot steer gaining 2.05 kg per day. Treatment diets were ground corn and bloodmeal based, balanced for amino acids, and contained differing levels of available and unavailable fiber. The first treatment diet contained $10 \%$ orchard grass hay $(\mathrm{BM}+$ Hay $)$, the second diet contained no roughage $(\mathrm{BM})$, the third diet contained cottonseed hulls $(\mathrm{BM}+\mathrm{CSH})$ to match the undegradable fiber fraction of the hay diet, and the fourth diet contained soybean hulls $(\mathrm{BM}+\mathrm{SH})$ to match the degradable fiber fraction of the hay diet. Treatment $\mathrm{pH}$ values
\end{abstract}


differed $(P<0.05)$ with the $\mathrm{BM}+$ Hay treatment having the highest $\mathrm{pH}$ value when compared to the other treatments, whose $\mathrm{pH}$ values did not differ $(P>0.05)$. Treatment ammonia levels differed $(P<0.05)$ with the $\mathrm{BM}+$ Hay treatment having the highest ammonia level when compared to the remaining treatments. Microbial efficiency calculations did not differ $(P>0.05)$ among treatments. Total volatile fatty acid (VFA) concentrations differed $(P<0.05)$ with treatments containing roughage and fiber sources having higher total VFA concentrations. True dry matter (DM) and true organic matter $(\mathrm{OM})$ digestibility differed between treatments with the BM treatment having a higher digestibility when compared to the diets containing hay, soybean hulls, or cottonseed hulls. Neutral detergent fiber digestibility values did not differ $(P>0.05)$ across treatments, but were lower than values provided by NRC tables (i.e. 80\% TDN for soybean hulls). The reduced NE value of fibrous feedstuffs, if adjusted, would decrease the NE system's ability to account for energy utilization by approximately $4 \%$.

\section{INTRODUCTION}

Growing and finishing feedlot diets typically contain a roughage source at a level of 5 to $15 \%$ to maintain rumen health and prevent acidosis and liver abscesses (Loerch and Fluharty, 1998). Research conducted to remove roughage from feedlot diets resulted in decreased performance (Murphy and Loerch, 1994; Bartle and Preston, 1991). Willis and Kerley (2004), however, found that adding roughage to the growing and finishing ration increased feed to gain, resulting in increased total feed costs to produce a carcass with no impacts on growth. 
Removal of roughage and the meeting of absorbable amino acid requirements in the feedlot diet have led to improved gain efficiencies that were not accurately described by NE system calculations (Willis and Kerley, 2004; Mueller, 2004). There data (Willis and Kerley, 2004) along with the results from chapter two led us to believe that NDF fiber digestibility in high concentrate diets may be lower than reported values. Thus, energy values of fibrous feedstuffs may need to be adjusted for digestibility if the NE system is to provide an accurate account of energy utilization. Therefore, the objectives of this study were to determine the NDF digestibility of differing fiber sources in high concentrate feedlot diets and to determine if reduced NDF fiber digestibility of high concentrate diets could influence NE calculations. It was hypothesized that reduced fiber digestion in high concentrate diets would cause diet NE discrepancies.

\section{MATERIALS AND METHODS}

\section{Continuous Culture System}

The single flow continuous culture (CC) system previously described by Meng et al. (1999) consisted of 24 polycarbonate vesicles each having a 2,000 $\mathrm{ml}$ capacity (Fisher Scientific, Pittsburgh, PA). The top cover of each vesicle was fitted with input ports for buffer, carbon dioxide, feed, and a $\mathrm{pH}$ electrode. The side of each vessel contained an outlet that held the liquid volume of the fermentor at 1,460 $\mathrm{ml}$ and allowed contents to flow out of the vessel above that volume. The buffer DR was maintained using a peristaltic pump (Masterflex model 7520-10, Cole Palmer Instrument Co., Chicago, IL). The temperatures of the culture vesicles were maintained at $39^{\circ} \mathrm{C}$ using a water bath 
heated by a thermostatically controlled water heater (Model 730, Fisher Scientific). A magnetic stir plate (Thermix Stirrer Model 120S, Fisher Scientific) placed under each culture vessel and water bath continually stirred the fermentor to keep feed particles suspended in the culture. Each culture vessel was continuously flushed with carbon dioxide to maintain anaerobic conditions.

Twenty-four single flow CC fermentors were inoculated with a 1:1 ratio of McDougall's buffer and rumen fluid collected from two lactating dairy cows consuming a corn silage diet supplemented with concentrate. The rumen fluid was strained through two layers of cheesecloth at the time of collection and placed in insulated containers for transport to the laboratory. Once at the laboratory the rumen fluid from both dairy cows was combined and mixed with the buffer solution. The $1,460 \mathrm{ml}$ of the resulting mixture was added to each fermentor.

The treatment diets and their chemical composition are listed in Table 1. Treatment diets were ground corn and bloodmeal based, balanced for amino acids, and contained differing levels of available and unavailable fiber. Treatment diets were formulated using empirical equations described previously by Mueller (2004) to estimate the rumen undegradable protein (RUP) essential amino acid (EAA) flow from the rumen. The diets were formulated to meet the requirements of growing/finishing steers within the weight range of 301 to $391 \mathrm{~kg}$, consuming $6.35 \mathrm{~kg}$ of dry matter per day and gaining approximately $2 \mathrm{~kg}$ per day. The Cornell Net Carbohydrate and Protein System (CNCPS; version 3.0, 1994) was used to estimate the EAA requirements for growth. The first treatment diet contained $10 \%$ orchard grass hay, the second diet contained no roughage, the third diet contained cottonseed hulls to match the undegradable fiber fraction of the 
hay diet, and the fourth diet contained soybean hulls to match the degradable fiber fraction of the hay diet. Sixty grams of diet were fed in two equal portions daily at 0900 hours and 2100 hours. All diet components were ground through a Willey Mill to pass through a $2.0 \mathrm{~mm}$ screen before being mixed together.

The DR across treatments remained constant at 0.04 /hour and was chosen to simulate a dry matter intake (DMI) equal to or less than $2 \%$ of body weight (BW). Six culture vessels were randomly assigned to each diet. The buffer (Slyter, 1990) used during the experiment had a high buffering capacity and was used in anticipation of more acid production due to the high starch content of the diet.

Sample collection and analyses

The fermentor volume was allowed to turn over four times to achieve a steady state microbial population before beginning to collect effluent (Meng et al., 1999). Fermentor effluent volumes were collected for 72 hours in individual containers submerged in an ice bath. Each collection container was dosed with $37 \%$ formaldehyde solution (Fisher Scientific) added at a level of approximately 2.5\% of the expected effluent volume to stop microbial activity. Total effluent was collected and measured every 24 hours to determine the actual DR. From each sampling period approximately $1,000 \mathrm{ml}$ of fermentor effluent was subsampled from the total for further analysis and then pooled and stored at $4^{\circ} \mathrm{C}$. A subsample $(1,050 \mathrm{ml})$ of the pooled effluent was further divided into six centrifuge tubes, each containing $175 \mathrm{ml}$, and centrifuged at 30,000 x $g$ for 30 minutes at $4^{\circ} \mathrm{C}$. The resulting supernatant was poured off and the remaining pellet was washed with $25 \mathrm{ml}$ of a $0.85 \%$ saline solution and re-spun at 30,000 $\mathrm{x} g$ for 30 minutes at $4^{\circ} \mathrm{C}$. The resulting supernatant was again poured off and the remaining pellet 
was washed with distilled water and re-spun at $30,000 \times \mathrm{g}$ for 30 minutes at $4^{\circ} \mathrm{C}$.

Following the final spin the supernatant was once again poured off and the remaining pellet transferred to a weighed container and stored at $-80^{\circ} \mathrm{C}$.

At termination of the experimental period approximately $40 \mathrm{ml}$ of a $37 \%$ formaldehyde solution was added to each fermentor. The fermentor contents were then blended in a commercial blender for 3 minutes, strained through four layers of cheesecloth and stored at $4{ }^{\circ} \mathrm{C}$. A subsample $(1,050 \mathrm{ml})$ of the fermentor content volume was further divided into six clear polyurethane centrifuge tubes, each containing $175 \mathrm{ml}$, and centrifuged at $1,000 \times \mathrm{g}$ for 5 minutes at $4^{\circ} \mathrm{C}$. The resulting supernatant was transferred to another centrifuge tube, careful not to include the pellet, and then spun at $27,000 \times g$ for 30 minutes at $4^{\circ} \mathrm{C}$. The resulting supernatant was aspirated off and the remaining pellet was washed with a $0.85 \%$ saline solution and re-spun at $27,000 \mathrm{x} g$ for 30 minutes at $4^{\circ} \mathrm{C}$. The supernatant was poured off and the remaining pellet was transferred to a weighed container and stored at $-80^{\circ} \mathrm{C}$.

Two $5.0 \mathrm{ml}$ samples were taken daily at 1300 hours during effluent collection for VFA, ammonia-N, and peptide analysis. The VFA and ammonia-N samples were preserved with $50 \mu \mathrm{l}$ of $6 \mathrm{~N} \mathrm{HCl} / \mathrm{ml}$ and the peptide sample was preserved with $50 \mu \mathrm{l}$ of $\mathrm{HgCl}_{2} / \mathrm{ml}$ (Ludden and Kerley, 1997). Samples were stored at $-80^{\circ} \mathrm{C}$ until further analysis could be done. The nitrogen content of the diets, isolated microorganisms, and effluent residue were determined using a LECO FP-428 Nitrogen Determinator (Leco Co., St. Paul, MN). Crude protein content was estimated as nitrogen x 6.25. Neutral detergent fiber and acid detergent fiber (ADF) analysis were done using an Ankom fiber analyzer (Ankom Model 200, Fiber analyzer, Ankom Technology, Fairport, NY). The 
OM and DM content of the diet were determined by AOAC (1984) protocol. True digestibility of DM and OM were calculated as the difference between DM and OM fed to the fermenters minus the effluent residues (Slyter, 1990).

The VFA samples were thawed in a cold water bath and centrifuged at 20,000 $\mathrm{x} g$ for 20 minutes at $4^{\circ} \mathrm{C}$. Of the resulting supernatant $1 \mathrm{ml}$ was pipetted off and put into a $1.5 \mathrm{ml}$ microcentrifuge tube. To this $200 \mu \mathrm{l}$ of metaphosphoric acid (25\% wt/vol) and 2ethylbutyric acid was added. The metaphosphoric acid served to precipitate out the proteins and 2-ethylbutyric acid served as an internal standard. The samples were mixed and then spun for 15 minutes at 30,000 x g. One $\mathrm{ml}$ of sample was then pipetted into DP vials and analyzed using gas chromatography (Model 3400, Varian, Walnut Creek, CA) as described by Grigsbey et al. (1992).

Ammonia-N concentrations were determined using a phenol-hyperchlorite colorimetric procedure according to Broderick and Kang (1980). The ammonia samples were thawed in a cold water bath and upon thawing were vortexed to ensure mixing. Two $\mathrm{ml}$ of sample was pipetted off and placed into a labeled $2 \mathrm{ml}$ microcentrifuge tube and spun at 20,000 x $\mathrm{g}$ for 15 minutes. Of the resulting supernatant $20 \mu \mathrm{l}$ was transferred and mixed with $2.5 \mathrm{ml}$ of a phenol reagent in a cuvette. Two $\mathrm{ml}$ of sodium hypochlorite reagent was then added and vortexed. Marbles were placed on top of the cuvettes at which point they were placed into a $95^{\circ} \mathrm{C}$ waterbath for five minutes. Upon cooling samples were measured for ammonia-N concentrations using a DU-50 spectrometer (Beckman, Palo Alto, CA).

Lactic acid concentrations were determined by thawing the VFA samples in a cold water bath and centrifuging them at $20,000 \times \mathrm{g}$ for 20 minutes at $4{ }^{\circ} \mathrm{C}$. Of the 
resulting supernatant $1 \mathrm{ml}$ was pipetted off and put into a cuvette with three drops of $6 \mathrm{~N}$ $\mathrm{HCl} / \mathrm{ml}$. To this $100 \mu \mathrm{l}$ of 2-methyl butyric acid $(18,461 \mathrm{mg} / \mathrm{ml})$ was added, which served as an internal standard for the VFA analysis. Three standards were prepared by adding three drops of $6 \mathrm{~N} \mathrm{NaOH} / \mathrm{ml}$ with $1 \mathrm{ml}$ of a mixture of acetic acid $(3,444 \mathrm{mg} / \mathrm{ml})$, propionic acid $(1,021 \mathrm{mg} / \mathrm{ml})$, isobutyric acid $(452 \mathrm{mg} / \mathrm{ml})$, butyric acid $(1,069 \mathrm{mg} / \mathrm{ml})$, isovaleric acid $(418 \mathrm{mg} / \mathrm{ml})$, valeric $(418 \mathrm{mg} / \mathrm{ml})$ and lactic acid $(470 \mathrm{mg} / \mathrm{ml})$. To this $100 \mu 1$ of 2-methyl butyric acid $(18,461 \mathrm{mg} / \mathrm{ml})$ was added, which served as an internal standard for the VFA and lactic acid analysis. All samples were then placed in a $55^{\circ} \mathrm{C}$ drying oven for 5 days. One $\mathrm{ml}$ of sample was then pipetted into DP vials and analyzed using gas chromatography (Model 3400, Varian, Walnut Creek, CA) as described by Grigsbey et al. (1992).

Statistical Analysis

Dilution rate, $\mathrm{pH}$, ammonia, MOEFF, volatile fatty acids, fiber digestibility, true and apparent dry matter digestibility, and true and apparent organic matter digestibility were analyzed using the general linear model of SAS (2002-2008). Fermentor was experimental unit. Differences between treatments were determined using Fisher's least significant difference statement of SAS (2002-2008). Significant differences were determined at the $\mathrm{P}<0.05$ level.

\section{RESULTS AND DISCUSSION}

The desired DR for all treatments during the experiment was $0.04 /$ hour. The measured average DR over the collection period was $0.0402 /$ hour for all treatments with 
the average DR for each treatment given in Table 3.2. The difference between the desired DR and the recorded DR was small and was attributed to the difficulty in setting the peristaltic pumps and the elasticity of the tubing.

Treatment $\mathrm{pH}$ measurements of fermenters taken four hours post-feeding are shown in Table 3.2. Treatment $\mathrm{pH}$ values differed $(P<0.05)$ with the BM+Hay treatment having the highest $\mathrm{pH}$ value when compared to the other treatments, whose $\mathrm{pH}$ values did not differ $(P>0.05)$.

Treatment ammonia concentrations are shown in Table 3.2. Treatment ammonia levels differed $(P<0.05)$ with the $\mathrm{BM}+$ Hay treatment having the highest ammonia level when compared to the remaining treatments. Microbial efficiency calculations did not differ $(P>0.05)$ among treatments (Table 3.2).

Volatile fatty acid results are shown in Table 3.3. Total VFA concentrations differed $(P<0.05)$ with treatments containing roughage and fiber sources having higher total VFA concentrations. Lactic acid concentration differed $(P<0.05)$ and was highest in the $\mathrm{BM}+\mathrm{Hay}$ diet with the $\mathrm{BM}$ diet having the lowest. Acetic acid concentrations were highest with treatments containing roughage and fiber sources. There was no difference $(P<0.05)$ in the ratio of acetic acid to propionic acid between treatments.

True DM and true OM digestibility differed between treatments with the BM treatment having a higher digestibility when compared to the diets containing hay, soybean hulls, or cottonseed hulls (Table 3.4). Neutral detergent fiber digestibility values did not differ $(P>0.05)$ across treatments (Table 3.4) but were much lower than reported values in the NRC (2001). Calsamiglia et al. (2002) concluded that $\mathrm{pH}$ values less than 5.8 impaired the digestive capabilities of fiber degrading bacteria as they were $\mathrm{pH}$ 
sensitive. The average $\mathrm{pH}$ measurement of all treatments 4 hours post-feeding was lower than the optimal $\mathrm{pH}$ of 5.8 and above.

To account for reduced energy concentration of the diet due to reduced fiber digestibility the following calculations were done. First, the average diet NDF percentage was multiplied by the tabular digestibility value. This sum was then multiplied by the remaining diet percentage and a digestibility value of $100 \%$. Secondly, the average diet NDF percentage was multiplied by the measured digestibility value, whose sum was then multiplied by the remaining diet percentage and a digestibility value of $100 \%$. Thirdly, the two resulting values were expressed as a ratio (measured digestibility/tabular digestibility). The example provided below utilized values from the trial with the average treatment percent NDF equal to $15 \%$ and the average NDF digestibility for all treatments equaling $21 \%$.

1. [Diet NDF (15\%)* Digestibility (Tabular Value 45\%)]* [Remaining Diet $(85 \%) *$ Digestibility $(100 \%)]=91.75$

2. [Diet NDF (15\%)* Digestibility (21\%)]* [Remaining Diet (85\%)* Digestibility $(100 \%)]=88.09$

3. $88.09 / 91.75=96 \%$ or $4 \%$ Adjustment

The resulting $4 \%$ adjustment due to decreased fiber digestibility would further decrease the ability of the NE system to describe energy utilization by the animal. 


\section{CONCLUSION}

The reduced NE value of fibrous feedstuffs, if adjusted, decreased the NE system's ability to account for energy utilization by approximately $4 \%$. Though we see a decrease in NDF digestibility in feedlot rations, because the NDF fraction is small relative to the remaining components the overall impact of decreased NDF digestibility on explaining NE discrepancies is small. 
Table 3.1. Ingredients and chemical composition of continuous culture diets

\begin{tabular}{lcccc}
\hline & \multicolumn{4}{c}{ Diets $^{1}$} \\
\cline { 2 - 5 } Ingredients $^{2}$ & BM & BM+Hay & BM+CSH & BM+SH \\
\hline Corn & 90.9 & 78.3 & 85.5 & 82.1 \\
Bloodmeal & 8.5 & 11.1 & 10.5 & 10.0 \\
Grass hay & --- & 10.0 & --- & --- \\
Cottonseed hulls & --- & --- & 3.4 & --- \\
Soybean hulls & --- & --- & --- & 7.3 \\
KCl & 0.6 & 0.6 & 0.6 & 0.6
\end{tabular}

Chemical Composition ${ }^{3}, \%$ of DM

\begin{tabular}{lcccc}
\hline DM & 91.2 & 91.5 & 91.3 & 91.4 \\
CP & 18.73 & 18.86 & 19.07 & 18.66 \\
NDF & 11.62 & 18.86 & 15.22 & 14.85 \\
ADF & 2.78 & 7.14 & 5.41 & 6.16 \\
Ash & 2.43 & 2.95 & 2.37 & 2.63 \\
\hline
\end{tabular}

${ }^{1} \mathrm{BM}=$ bloodmeal; $\mathrm{CSH}=$ cottonseed hulls; $\mathrm{SH}=$ soybean hulls

${ }^{2} \mathrm{KCl}=$ potassium chloride

${ }^{3} \mathrm{DM}=$ dry matter; $\mathrm{CP}=$ crude protein $; \mathrm{NDF}=$ neutral detergent fiber; $\mathrm{ADF}=$ acid detergent fiber 
Table 3.2. Continuous Culture Results

\begin{tabular}{l|cccc}
\hline \multirow{2}{*}{ Item } & \multicolumn{4}{|c}{ Treatment Diets $^{1}$} \\
\cline { 2 - 5 } & BM & BM+CSH & BM+Hay & BM+SH \\
\hline Dilution Rate & 4.15 & 3.93 & 4.00 & 4.02 \\
$\mathrm{pH}$ & $5.07^{\mathrm{b}}$ & $5.00^{\mathrm{b}}$ & $5.38^{\mathrm{a}}$ & $5.11^{\mathrm{b}}$ \\
Ammonia (mM) & $4.12^{\mathrm{b}}$ & $6.24^{\mathrm{b}}$ & $15.22^{\mathrm{a}}$ & $4.78^{\mathrm{b}}$ \\
MOEFF $^{2}$ & 20.54 & 22.11 & 24.47 & 23.60 \\
\hline
\end{tabular}

${ }^{\mathrm{I}} \mathrm{BM}=$ bloodmeal; $\mathrm{CSH}=$ cottonseed meal; $\mathrm{SH}=$ soybean hulls

${ }^{2} \mathrm{MOEFF}=$ microbial efficiency

${ }^{\mathrm{a}, \mathrm{b}}$ Means within row lacking a common superscript differ $(\mathrm{P}<0.05)$. 
Table 3.3. Continuous culture volatile fatty acid results

\begin{tabular}{l|cccc}
\hline \multirow{2}{*}{ Item } & \multicolumn{4}{|c}{ Treatment Diets } \\
\cline { 2 - 5 } & BM & BM+CSH & BM+Hay & BM+SH \\
\hline Total VFA $(\mathrm{mM})$ & $118.05^{\mathrm{b}}$ & $145.91^{\mathrm{a}}$ & $140.79^{\mathrm{a}, \mathrm{b}}$ & $144.25^{\mathrm{a}}$ \\
Lactic Acid (mM) & $0.20^{\mathrm{b}}$ & $0.36^{\mathrm{a}, \mathrm{b}}$ & $0.53^{\mathrm{a}}$ & $0.31^{\mathrm{a}, \mathrm{b}}$ \\
Acetic Acid (mM) & $45.51^{\mathrm{b}}$ & $64.64^{\mathrm{a}}$ & $58.61^{\mathrm{a}, \mathrm{b}}$ & $53.42^{\mathrm{a}, \mathrm{b}}$ \\
Propionic Acid (mM) & $25.63^{\mathrm{b}}$ & $34.65^{\mathrm{b}}$ & $30.31^{\mathrm{b}}$ & $49.11^{\mathrm{a}}$ \\
Isobutyric Acid (mM) & $0.82^{\mathrm{b}}$ & $1.00^{\mathrm{b}}$ & $1.86^{\mathrm{a}}$ & $1.06^{\mathrm{b}}$ \\
Butyric Acid (mM) & $38.14^{\mathrm{a}}$ & $35.01^{\mathrm{a}, \mathrm{b}}$ & $40.52^{\mathrm{a}}$ & $27.99^{\mathrm{b}}$ \\
Isovaleric Acid (mM) & $1.21^{\mathrm{b}}$ & $1.54^{\mathrm{b}}$ & $3.16^{\mathrm{a}}$ & $1.53^{\mathrm{b}}$ \\
Valeric Acid (mM) & $6.55^{\mathrm{b}, \mathrm{c}}$ & $8.72^{\mathrm{a}, \mathrm{b}}$ & $5.81^{\mathrm{c}}$ & $10.84^{\mathrm{a}}$ \\
Acetic:Proprionic & 1.78 & 1.87 & 1.93 & 1.09 \\
\hline
\end{tabular}

${ }^{1} \mathrm{BM}=$ bloodmeal; $\mathrm{CSH}=$ cottonseed meal; $\mathrm{SH}=$ soybean hulls

${ }^{2} \mathrm{VFA}=$ volatile fatty acid

${ }^{\mathrm{a}, \mathrm{b}, \mathrm{c}}$ Means within row lacking a common superscript differ $(\mathrm{P}<0.05)$. 
Table 3.4. Continuous culture digestibility results

\begin{tabular}{l|cccc}
\hline \multirow{2}{*}{ Item $^{2}$} & \multicolumn{4}{|c}{ Treatment Diets } \\
\cline { 2 - 5 } & BM & BM+CSH & BM+Hay & BM+SH \\
\hline Fiber digestibility & 20.10 & 26.00 & 15.90 & 21.80 \\
True DM Dig & $70.74^{\mathrm{a}}$ & $65.79^{\mathrm{b}}$ & $65.16^{\mathrm{b}}$ & $65.16^{\mathrm{b}}$ \\
Apparent DM Dig & 55.61 & 50.09 & 51.18 & 49.29 \\
True OM Dig & $71.71^{\mathrm{a}}$ & $66.90^{\mathrm{b}}$ & $66.17^{\mathrm{b}}$ & $66.23^{\mathrm{b}}$ \\
Apparent OM Dig & 58.84 & 53.67 & 53.25 & 52.86 \\
\hline
\end{tabular}

${ }^{1} \mathrm{BM}=$ bloodmeal; $\mathrm{CSH}=$ cottonseed meal; $\mathrm{SH}=$ soybean hulls

${ }^{2} \mathrm{DM}=$ dry matter; $\mathrm{OM}=$ organic matter

${ }^{\mathrm{a}, \mathrm{b}}$ Means within row lacking a common superscript differ $(\mathrm{P}<0.05)$. 


\title{
CHAPTER IV
}

\section{DETERMINING THE EFFECTS OF DIETARY ARGININE LEVEL ON SUBSEQUENT FEEDLOT PERFORMANCE AND EFFICIENCY}

\begin{abstract}
A study was conducted to determine the effects of dietary arginine level on subsequent feedlot cattle performance and efficiency. The ruminally degradable protein (RDP) in the diet met, but did not exceed predicted degradable nitrogen required to maximize microbial efficiency. Dietary arginine levels were contrasted to test the hypothesis that diets could be formulated, based on absorbable amino acid requirements. The diets were whole corn based and contained a vitamin-mineral premix with Rumensin. The control diet (hay) was formulated to mimick a typical feedlot ration containing $10 \%$ chopped hay. The remaining three diets differed in the level of arginine supplied to the animal with the first diet formulated to supply $85 \%$ of the animal's arginine needs (85), the second diet formulated to supply $100 \%$ of the animal's arginine needs (100), and the third diet formulated to supply $115 \%$ of the animal's arginine needs (115). All diets were formulated to achieve an average daily gain (ADG) of $2.30 \mathrm{~kg}$ during phase one (P1; Days 0 to 42), $1.80 \mathrm{~kg}$ during phase two (P2; Days 43 to105), and $1.60 \mathrm{~kg}$ during phase three (P3; Days 106 to 188). Diets were optimized for RDP and microbial crude protein estimates were calculated using empirical equations used previously by Mueller (2004) to estimate the rumen undegradable protein (RUP) essential
\end{abstract}


amino acid (EAA) flow from the rumen. Amino acid requirements of feedlot steers were based upon the original CNCPS. The ADG did not differ $(\mathrm{P}>0.05)$ during $\mathrm{P} 1$ for 115 , 100,85 , and Hay groups $(1.93,1.99,1.88$, and $1.72 \mathrm{~kg}$, respectfully). The GF differed (P $<0.05)$ during $\mathrm{P} 1$ for $115,100,85$, and Hay groups $(0.25,0.25,0.23$ and 0.20 , respectfully) with 115,100 , and 85 cattle having a greater GF ratio than Hay. The ADG did not differ $(\mathrm{P}>0.05)$ during $\mathrm{P} 2$ for $115,100,85$, and Hay groups $(1.26,1.33,1.23$, and $1.25 \mathrm{~kg}$ per day, respectfully). The GF did not differ $(\mathrm{P}>0.05)$ during $\mathrm{P} 2$ for 115 , 100,85 , and Hay groups $(0.13,0.13,0.12$ and 0.12 , respectfully). The ADG did not differ $(\mathrm{P}>0.05)$ during $\mathrm{P} 3$ for 115, 100, 85, and Hay groups $(1.26,1.29,1.26$, and 1.14 kg per day, respectfully). The GF differed $(\mathrm{P}<0.05)$ during $\mathrm{P} 3$ for $115,100,85$, and Hay groups $(0.14,0.13,0.13$ and 0.12 , respectfully) with 115,100 , and 85 cattle having a greater GF ratio than Hay. We concluded from this research that animal performance can be improved when diets are formulated to meet absorbable amino acid requirement. Dietary arginine level provided above the requirement resulted in no improvement in performance, thus providing evidence for the accuracy and reliability of empirical equations used to estimate the rumen undegradable protein essential amino acid flow from the rumen.

\section{INTRODUCTION}

The efficiency by which cattle use nutrients for tissue accretion is a major determinant of profitability in the feedlot production phase. It is therefore imperative to 
understand the principles of protein and energy metabolism to better develop practical feeding programs for animals to maximize their genetic potential for production.

The net energy (NE) system separates the requirements for energy into maintenance and weight gain functions. This separation exists because the partial efficiency of energy utilization for maintenance is higher than it is for production (Kleiber, 1975).

The effective energy (EE) system likewise separates energy expenditure into the requirements for maintenance and growth, but further divides growth into energy required for protein retention and lipid retention (Emmans, 1994). The EE system more accurately assesses growth expenditures for the type of tissue accrued, believed to improve energy accounting by the animal compared to the NE system.

Feeding ruminally degradable protein (RDP) above what is needed for maximum microbial efficiency results in inefficient use of crude protein (CP) by the rumen microflora and, subsequently, the animal. Research conducted in our laboratory led to the conclusion that optimizing RDP in the diet (coordinating the RDP mass and rate of degradation with the microbial growth rate and fermentable carbohydrate mass and degradation rate) allowed for removal of roughage from the diet. It was also found that microbial amino acid (AA) flow to the small intestine could be predicted, thus allowing for the formulation of diets optimized to use rumen undegradable AA (RUAA) to meet the absorbable AA requirements of the calf.

The increased gain efficiency (assessed by feed conversion ratio) measured in cattle fed optimized diets was greater than biologically possible based upon NE system calculations. 
The objective of this experiment was to 1) verify that matching absorbable AA flow to absorbable AA requirement improved growth performance of steer calves in the feedlot; 2) determine the ability of predictive equations to match RUAA delivery from the diet with RUAA needs of the growing calf; 3) determine the effect of supplying differing levels of arginine on feedlot cattle performance and efficiency; and 4) evaluate the accuracy of EE relative to NE equations in determining energy expenditure by calves fed diets balanced for RUAA delivery.

\section{MATERIALS AND METHODS}

\section{Feedlot Steers and Management}

Crossbred Angus steers $(n=82)$ were randomly assigned to one of eight partially covered pens located in two pole-barns, upon arriving to the University of MissouriColumbia Beef Farm. The barns were located within 100 feet of each other, thus allowing for similar environmental conditions to be maintained between pens. Each pen had concrete flooring, was of the same approximate size and dimensions, and half of each pen was covered by the sloped roof of the barn. Feed-bunks were located at the north end of each pen and were covered and protected from environmental elements by the barn walls and roof structure. Frost-free waterers were located in the uncovered portion of each pen.

Before arrival to the University of Missouri-Columbia Beef Farm all animals had been individually identified with plastic tags in the right and left ears, vaccinated for IBR-two doses, BVD-two doses, PI3-two doses, bovine respiratory syncytial virus-two 
doses, pasteurella hemolytica-one dose, a seven-way blackleg-two doses, and haemophilus somnus-two doses. All animals were surgically castrated and dewormed and treated for external parasites. No growth promoting implants were used.

Upon arrival to the University Beef Farm all animals were weighed and individually identified by inserting an electronic identification transponder button (Allflex USA, Inc., Dallas-Ft. Worth Airport, TX, USA) into its right ear. The steers were placed on a receiving diet for 14 days. Water and diet during this period were provided ad libitum.

Following the receiving period steers were weighed on consecutive days to establish a beginning weight, stratified to pens by weight, and provided the experimental diets. Treatment diets consisted of a positive control (10\% hay) and three diets without roughage and formulated to optimize RDP and provide varying levels of RUAA (Tables 4.1, 4.2 and 4.3). The first limiting amino acid of feedlot steers fed diets consisting primarily of whole corn was found to be arginine. The three diets differed in the level of arginine supplied to the animal with the first diet formulated to supply $85 \%$ of the animal's arginine needs (85), the second diet formulated to supply $100 \%$ of the animal's arginine needs (100), and the third diet formulated to supply $115 \%$ of the animal's arginine needs (115).

All diets were formulated to achieve an average daily gain (ADG) of $2.30 \mathrm{~kg}$ during phase one (P1; Days 0 to 42), $1.80 \mathrm{~kg}$ during phase two (P2; Days 43 to 105), and $1.60 \mathrm{~kg}$ during phase three (P3; Days 106 to 188). The protein levels of the diets varied depending of the ability of the protein to deliver the most limiting RUAA. Diets consisted primarily of whole shell corn and a pelleted protein source/ground corn 
supplement with vitamins and minerals with Rumensin. Diets were optimized for rumen degradable protein and microbial crude protein estimates were calculated using empirical equations. Amino acid requirements of feedlot steers were based upon the original CNCPS.

Net energy requirements were calculated using animal growth data and feed energy values found in the beef National Research Council (NRC, 2000). The ratio of NE consumed to the NE required for the measured growth was calculated for each treatment group. Equations used to calculate NE during P1 are found in Table 4.4. Effective energy requirements were calculated using measured animal growth data and equations based on work done by Emmans (1994). The ratio of EE consumed to the EE required for the measured growth was calculated for each treatment group. Equations used to calculate EE during P1 are found in table 4.5.

Each of the rations were mixed together as a total mixed ration (TMR) using a truck mounted paddle mixer. Steers were fed once daily and had ad libitum access to water and feed. Steers were weighed on single days at 21-day intervals following the initiation of the feeding trial and on two consecutive days at the termination of the trial to allow for average daily gain and feed efficiency calculations. Experimental procedures were conducted under an approved Animal Care and Use Protocol as regulated by the University of Missouri Animal Care and Use Committee.

\section{Feed Intake Measurement}

Individual animal feed intakes were collected using the GrowSafe individual animal feed intake system (GrowSafe Systems, Ltd., Alberta, Canada). Each pen featured two feeding bunks that allowed single animal access to a feed tub suspended on 
load cells. Intake data and feeding behavior were analyzed using the GrowSafe feed intake analysis software. This allowed for individual feed intake data to be obtained and for each animal to serve as the experimental unit.

Statistical Analysis

Initial weight, ending weight, average daily gain, dry matter intake, feed to gain, hot carcass weight, rib eye area, backfat thickness, and yield grade were analyzed using the general linear model of SAS (2002-2008). Animal was experimental unit. Differences between treatments were determined using Fisher's least significant difference statement of SAS (2002-2008). Significant differences were determined at the $\mathrm{P}<0.05$ level.

\section{RESULTS AND DISCUSSION}

Starting and ending weights did not differ $(\mathrm{P}>0.05)$ between treatment groups (Table 4.6). Trial ADG differed $(\mathrm{P}<0.05)$ with the $100-\mathrm{AR}$ treatment group having a greater ADG than the Hay treatment group (Table 4.6). Trial DMI intake differed (P < 0.05) with the Hay treatment having the greatest DMI (Table 4.6). Trial GF differed (P < 0.05 ) with $100-\mathrm{AR}, 115-\mathrm{AR}$, and $85-\mathrm{AR}$ having a greater GF ratio than Hay.

Animals consuming 100-AR and 115-AR diets, during period 1, had greater ADG values when compared to the 85-AR and Hay groups (Table 4.6), but this difference was not statistically significant $(\mathrm{P}>0.05)$. Average daily gain did not differ in periods 2 or 3 $(\mathrm{P}>0.05)$ (Table 4.6). Compared to animals of similar size, the ADG values reported in this trial were better than those reported by Barajas and Zinn (1998) and Zinn et al. 
(1998), in which traditional corn-based feedlot diets with roughage were fed. Average daily gain values from this study were better than those reported by Murphy and Loerch (1994), Kolath (2006), and Alkire (2007), in which all-concentrate diets were fed. The ADG values from this study were similar to those reported by Mueller (2004), Willis and Kerley (2004) and values reported previously in chapter 2 where no roughage diets were fed.

Dry matter intake was greater for animals in the Hay treatment when compared to animals consuming the no-roughage diets, however this difference was not statistically significant $(\mathrm{P}>0.05)$ during periods 1 and 3 (Table 4.6). Dry matter intake differed between treatments during period 2 with the hay treatment having a greater DMI $(\mathrm{P}<$ 0.05) than 85-AR and 115-AR treatment groups (Table 4.6). Feedlot studies using traditional diets with roughage and using animals of similar size reported intakes of 7.2 to $9.2 \mathrm{~kg}$ (Barajas and Zinn, 1998; Lehmkuhler, 2001; Zinn et al. 1997; 1998), whereas feedlot studies using all-concentrate diets reported intakes of 6.1 to $9.2 \mathrm{~kg}$ (Murphy and Loerch, 1994; Mueller, 2004; Willis and Kerley, 2004; Golden; 2004; Kolath, 2006; Alkire, 2007).

The GF ratio differed $(\mathrm{P}<0.05)$ during periods 1 and 3 for 100-AR, 115-AR, 85AR, and Hay groups, with 100, 115, and 85 cattle having a greater GF ratio than Hay (Table 4.6).

No differences $(\mathrm{P}>0.05)$ were noted in $\mathrm{HCW}$, fat thickness, or marbling scores between treatment groups (Table 4.7). Rib eye area of the 115-AR treatment group was greater $(\mathrm{P}<0.05)$ than animals in the 85 or 100 -AR treatment groups (Table 4.7$)$. 
Average yield grade values were greatest in the 85-AR treatment group and differed $(\mathrm{P}<$ 0.05 ) with animals in the 115-AR treatment group (Table 4.7).

Net energy and effective energy calculations are provided in Table 4.8. During both P1 and P2 of the feeding trial effective energy calculations were more capable of accurately assessing energy expenditure among maintenance, protein retention, and lipid retention (Table 4.8). When optimized diets are fed it is concluded that the net energy system cannot accurately predict measured growth efficiencies. Using more descriptive measures of maintenance heat expenditure, effective energy predictions would capture the FCR range expected among animals. Assessing nutritional and genetic influence on FCR should be based upon the effective energy system rather than the net energy system.

\section{CONCLUSION}

Growth and feed efficiency were improved when diets were formulated to meet the absorbable amino acid requirements of the feedlot steer.

The feeding of optimized diets led to predictive deficiencies when using net energy system calculations. By utilizing effective energy calculations we were better able to describe the energetic expenditures among maintenance, lipid retention, and protein retention functions. Assessing nutritional and genetic influence on FCR should be based upon the effective energy system rather than the net energy system. We concluded from this research that animal performance and feed efficiency can be improved when diets are formulated to meet the absorbable amino acid requirements of the feedlot steer. 
Table 4.1. First Phase Diet Composition

\begin{tabular}{|c|c|c|c|c|}
\hline \multirow[b]{2}{*}{ Item } & \multicolumn{4}{|c|}{ First Phase Diets } \\
\hline & Traditional & $85 \%$ Arg & $100 \% \mathrm{Arg}$ & $115 \%$ Arg \\
\hline Corn & 78.62 & 89.3 & 85.87 & 82.57 \\
\hline Bloodmeal & 2.7 & 1.5 & 5.1 & 8.7 \\
\hline DDGS & 5 & 5 & 5 & 5 \\
\hline Hay & 10 & --- & --- & --- \\
\hline Tallow & 2 & 1.72 & 2 & 2 \\
\hline Urea & 0.3 & 0.7 & 0.3 & --- \\
\hline Limestone & 1.0 & 1.1 & 1.1 & 1.1 \\
\hline $\mathrm{KCl}$ & 0.2 & 0.5 & 0.5 & 0.5 \\
\hline Salt & 0.1 & 0.1 & 0.05 & 0.05 \\
\hline Vitamin Mix ${ }^{1}$ & 0.05 & 0.05 & 0.05 & 0.05 \\
\hline Mineral premix $^{2}$ & 0.03 & 0.03 & 0.03 & 0.03 \\
\hline
\end{tabular}

${ }^{\mathrm{I}}$ Contained (as-fed basis) 4,000,000 IU of vitamin A, 800,000 IU of vitamin D, and 1,250 IU of vitamin $\mathrm{E} / \mathrm{kg}$.

${ }^{2}$ Contained (as-fed basis) $10 \% \mathrm{Fe}, 10 \% \mathrm{Mn}, 10 \% \mathrm{Zn}, 2 \% \mathrm{Cu}, 1,500 \mathrm{ppm} \mathrm{Se}, 1,000 \mathrm{ppm} \mathrm{I}$, and $500 \mathrm{mg} / \mathrm{kg}$ Co. 
Table 4.2. Second Phase Diet Composition

\begin{tabular}{|c|c|c|c|c|}
\hline \multirow[b]{2}{*}{ Item } & \multicolumn{4}{|c|}{ Second Phase Diets } \\
\hline & Traditional & $85 \%$ Arg & $100 \%$ Arg & $115 \%$ Arg \\
\hline Corn & 78.62 & 94.9 & 89.82 & 87.32 \\
\hline Bloodmeal & 2.7 & --- & 0.3 & 3.2 \\
\hline DDGS & 5 & --- & 5 & 5 \\
\hline Hay & 10 & --- & --- & --- \\
\hline Tallow & 2 & 1.72 & 2 & 2 \\
\hline Urea & 0.3 & 1.4 & 1.0 & 0.65 \\
\hline Limestone & 1.0 & 1.2 & 1.15 & 1.15 \\
\hline $\mathrm{KCl}$ & 0.2 & 0.55 & 0.5 & 0.5 \\
\hline Salt & 0.1 & 0.15 & 0.15 & 0.1 \\
\hline Vitamin Mix ${ }^{1}$ & 0.05 & 0.05 & 0.05 & 0.05 \\
\hline Mineral premix ${ }^{2}$ & 0.03 & 0.03 & 0.03 & 0.03 \\
\hline
\end{tabular}

${ }^{\mathrm{I}}$ Contained (as-fed basis) 4,000,000 IU of vitamin A, 800,000 IU of vitamin D, and 1,250 IU of vitamin $\mathrm{E} / \mathrm{kg}$.

${ }^{2}$ Contained (as-fed basis) $10 \% \mathrm{Fe}, 10 \% \mathrm{Mn}, 10 \% \mathrm{Zn}, 2 \% \mathrm{Cu}, 1,500 \mathrm{ppm} \mathrm{Se}, 1,000 \mathrm{ppm} \mathrm{I}$, and $500 \mathrm{mg} / \mathrm{kg}$ Co. 
Table 4.3. Third Phase Diet Composition

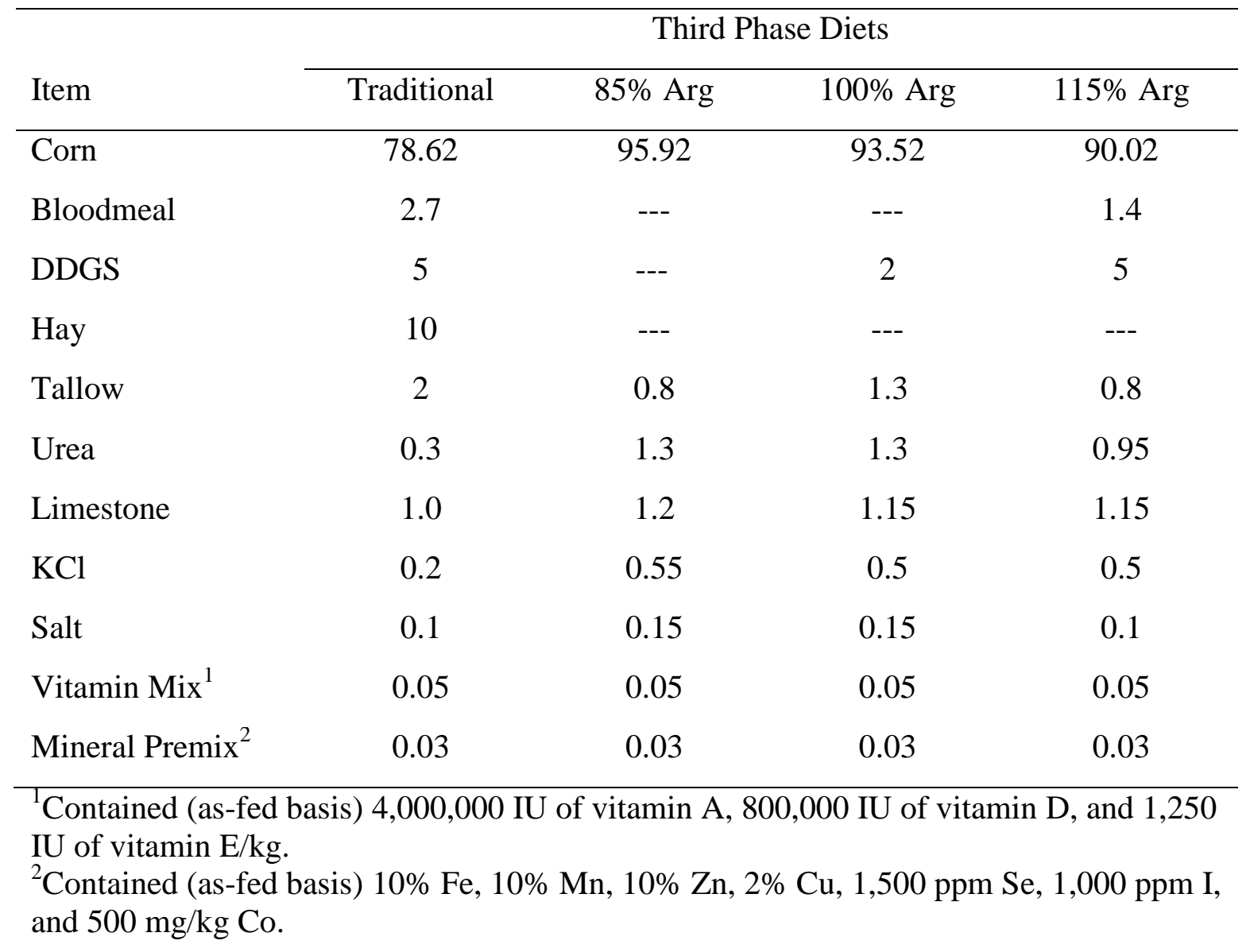


Table 4.4. Calculations for Net Energy

\begin{tabular}{lll}
\hline Term & Value & Calculation \\
\hline NEm of Diet & $2.15(\mathrm{Mcal} / \mathrm{kg})$ & \\
NEg of Diet & $1.48(\mathrm{Mcal} / \mathrm{kg})$ & \\
Day 42 Weight (D42wt) & $370.3 \mathrm{~kg}$ & \\
Shrunk body weight (SBW) & $355.5 \mathrm{~kg}$ & D42wt-(D42wt*0.04) \\
Average Daily Gain (ADG) & $1.99 \mathrm{~kg}$ & \\
Average Intake & $7.043 \mathrm{~kg}$ & \\
NEm requirement & $6.30 \mathrm{Mcal}$ & $0.077^{*}\left(\mathrm{SBW} \mathrm{W}^{\wedge} 0.75\right)$ \\
Feed to meet NEm & $2.93 \mathrm{~kg}$ & NEm requirement/NEm of diet \\
Available feed for NEg & $4.12 \mathrm{~kg}$ & Average intake-feed to meet NEm \\
Shrunk weight gain (SWG) & $1.91 \mathrm{~kg}$ & ADG-(ADG*0.04) \\
NEg required & $7.62 \mathrm{Mcal}$ & $\left(\mathrm{SWG} /\left(13.91^{*} \mathrm{SBW}{ }^{\wedge}-0.6837\right)\right)$ \\
NEg available & 5.64 & Available feed for NEg*NEg of diet \\
NE consumed to NE required & 0.74 & NEg available/NEg required \\
\hline
\end{tabular}


Table 4.5. Calculations for Effective Energy

\begin{tabular}{lll}
\hline Term & Value & Calculation \\
\hline Metabolizable Energy (ME) & $14.08 \mathrm{MJ} / \mathrm{kg}$ diet & \\
Crude Protein (CP) & 13.01 & \\
Empty Body Weight 1 (EBW1) & 331.71 & D42wt*0.891 \\
Empty Body Weight 2 (EBW2) & 329.94 & $(\mathrm{D} 42 \mathrm{wt}-\mathrm{ADG})^{*} 0.891$ \\
Effective Energy (EE) & $11.87 \mathrm{MJ} / \mathrm{kg}$ diet & $\left(\left(1.15^{*} \mathrm{ME}\right)-3.84-((4.67 *(\mathrm{CP} * 0.8 / 100)))\right.$ \\
EE/day & $83.57 \mathrm{MJ}$ & EE*Average intake \\
Maintenance Heat (MH) & $32514 \mathrm{KJ}$ & $\left(\mathrm{EBW} 2^{\wedge} 0.75\right)^{*} 420 \mathrm{KJ}$ \\
Body Protein for EBW1 & $61.23 \mathrm{~kg}$ & $\left(-2.418+\left(0.235^{*} \mathrm{EBW} 1\right)-\left(0.00013^{*} \mathrm{EBW} 1^{\wedge} 2\right)\right)$ \\
Body Protein for EBW2 & $60.97 \mathrm{~kg}$ & $\left(-2.418+\left(0.235^{*} \mathrm{EBW} 2\right)-\left(0.00013^{*} \mathrm{EBW} 2^{\wedge} 2\right)\right)$ \\
Protein Retention (PR) & $264.17 \mathrm{grams}$ & \\
Body Lipid for EBW1 & $71.08 \mathrm{~kg}$ & $\left(-0.61+\left(0.037^{*} \mathrm{EBW} 1\right)+\left(0.00054^{*} \mathrm{EBW} 1^{\wedge} 2\right)\right)$ \\
Body Lipid for EBW2 & $70.38 \mathrm{~kg}$ & $\left(-0.61+\left(0.037^{*} \mathrm{EBW} 2\right)+\left(0.00054^{*} \mathrm{EBW} 2^{\wedge} 2\right)\right)$ \\
Lipid Retention (LR) & $699.11 \mathrm{grams}$ & \\
EE requirement (EERQ) & $84.87 \mathrm{MJ}$ & $(\mathrm{MH}+(\mathrm{PR} * 50)+(\mathrm{LR} * 56)) / 1000$ \\
Ratio of EE to EERQ & 0.99 & $\mathrm{EE} / \mathrm{EERQ}$ \\
\hline
\end{tabular}


Table 4.6. Growth and efficiency results

\begin{tabular}{lcccc}
\hline & \multicolumn{3}{c}{ Treatments } \\
\cline { 2 - 5 } Item & Hay & 85 & 100 & 115 \\
\hline Initial Wt, kg & 284.55 & 279.36 & 288.58 & 285.62 \\
Final Wt, kg & 530.35 & 539.27 & 560.11 & 552.62 \\
Trial ADG 0-188, kg & $1.31^{\mathrm{b}}$ & $1.38^{\mathrm{a}, \mathrm{b}}$ & $1.44^{\mathrm{a}}$ & $1.42^{\mathrm{a}, \mathrm{b}}$ \\
Trial DMI 0-188, kg & $9.77^{\mathrm{a}}$ & $9.30^{\mathrm{a}, \mathrm{b}}$ & $9.48^{\mathrm{a}, \mathrm{b}}$ & $9.10^{\mathrm{b}}$ \\
Trial F:G 0-188 & $7.56^{\mathrm{a}}$ & $6.84^{\mathrm{b}}$ & $6.61^{\mathrm{b}}$ & $6.47^{\mathrm{b}}$ \\
Trial G:F 0-188 & $0.134^{\mathrm{b}}$ & $0.148^{\mathrm{a}}$ & $0.152^{\mathrm{a}}$ & $0.156^{\mathrm{a}}$ \\
P1 ADG 0-42, kg & 1.72 & 1.88 & 1.99 & 1.93 \\
P1 DMI 0-42, kg & 8.36 & 8.10 & 7.91 & 7.77 \\
P1 F:G 0-42 & $4.96^{\mathrm{a}}$ & $4.54^{\mathrm{a}, \mathrm{c}}$ & $4.07^{\mathrm{b}}$ & $4.12^{\mathrm{b}, \mathrm{c}}$ \\
P1 G:F 0-42 & $0.21^{\mathrm{b}}$ & $0.23^{\mathrm{a}}$ & $0.25^{\mathrm{a}}$ & $0.25^{\mathrm{a}}$ \\
P2 ADG 42-105, kg & 1.25 & 1.23 & 1.33 & 1.26 \\
P2 DMI 42-105, kg & $10.55^{\mathrm{a}}$ & $9.81^{\mathrm{a}, \mathrm{b}}$ & $10.24^{\mathrm{a}, \mathrm{b}}$ & $9.78^{\mathrm{b}}$ \\
P2 F:G 42-105 & 8.66 & 8.98 & 7.80 & 8.43 \\
P2 G:F 42-105 & 0.12 & 0.13 & 0.13 & 0.13 \\
P3 ADG 105-188, kg & 1.14 & 1.26 & 1.26 & 1.29 \\
P3 DMI 105-188, kg & 9.87 & 9.49 & 9.65 & 9.22 \\
P3 F:G 105-188 & $8.83^{\mathrm{a}}$ & $7.75^{\mathrm{b}}$ & $7.94^{\mathrm{b}}$ & $7.29^{\mathrm{b}}$ \\
P3 G:F 105-188 & $0.12^{\mathrm{b}}$ & $0.13^{\mathrm{a}}$ & $0.13^{\mathrm{a}}$ & $0.14^{\mathrm{a}}$ \\
ADG 0-21, kg & 1.83 & 1.90 & 2.03 & 1.99 \\
DMI 0-21, kg & 7.28 & 7.19 & 7.06 & 6.86 \\
F:G 0-21 & 4.38 & 5.25 & 4.02 & 3.96 \\
G:F 0-21 & 0.26 & 0.28 & 0.29 \\
\hline
\end{tabular}

${ }^{a, b, c}$ Means within row lacking a common superscript differ $(\mathrm{P}<0.05)$. 
Table 4.7. Carcass measurements

\begin{tabular}{lcccc}
\hline & \multicolumn{4}{c}{ Treatments } \\
\cline { 2 - 5 } Item & Hay & 85 & 100 & 115 \\
\hline $\mathrm{HCW}, \mathrm{kg}$ & 322.6 & 330.4 & 342.3 & 339.7 \\
REA, cm & & $73.15^{\mathrm{b}}$ & $73.61^{\mathrm{b}}$ & $80.57^{\mathrm{a}}$ \\
Fat thickness over the & 1.65 & 1.53 & 1.54 & 1.52 \\
$1^{\text {th }}$ rib, cm & & & & \\
KPH $^{\mathrm{I}}, \%$ & $1.62^{\mathrm{a}, \mathrm{b}}$ & $1.57^{\mathrm{a}, \mathrm{b}}$ & $1.52^{\mathrm{b}}$ & $1.68^{\mathrm{a}}$ \\
Marbling score & 4.62 & 4.92 & 4.73 & 4.53 \\
USDA yield grade $^{\mathrm{II}}$ & $2.86^{\mathrm{a}, \mathrm{b}}$ & $3.05^{\mathrm{a}}$ & $2.95^{\mathrm{a}, \mathrm{b}}$ & $2.67^{\mathrm{b}}$ \\
\hline
\end{tabular}

${ }^{\mathrm{a}, \mathrm{b}}$ Means within row lacking a common superscript differ $(\mathrm{P}<0.05)$.

${ }^{\mathrm{I}}$ Kidney, pelvic, and heart fat

II Marbling Scores: A score between 4.0 and 5.0 is equivalent to Low Choice 
Table 4.8. Energy Calculation Results for Net Energy and Effective Energy

\begin{tabular}{lllll}
\hline Diet & Hay & $85-\mathrm{AR}$ & $100-\mathrm{AR}$ & $115-\mathrm{AR}$ \\
\hline $\mathrm{P} 1 \mathrm{NE}^{1}$ & 0.95 & 0.85 & 0.74 & 0.75 \\
$\mathrm{P} 2 \mathrm{NE}^{1}$ & 1.51 & 1.43 & 1.34 & 1.34 \\
$\mathrm{P} 3 \mathrm{NE}^{1}$ & 1.16 & 0.99 & 0.98 & 0.89 \\
$\mathrm{P} 1 \mathrm{EE}^{2}$ & 1.13 & 1.07 & 0.99 & 0.99 \\
$\mathrm{P} 2 \mathrm{EE}^{2}$ & 1.48 & 1.44 & 1.41 & 1.40 \\
$\mathrm{P} 3 \mathrm{EE}^{2}$ & 1.26 & 1.16 & 1.16 & 1.09 \\
\hline
\end{tabular}

${ }^{1}$ Ratio of net energy consumed to that required.

${ }^{2}$ Ratio of effective energy consumed to that required. 


\section{LITERATURE CITED}

Alkire, D.O. 2007. The effects of supplemental rumen-protected fat in feedlot rations. Ph.D. Diss. Univ. of Missouri, Columbia. 44-85 pp.

AOAC. 1984. Official Methods Analysis. $14^{\text {th }}$ ed. Association of Official Analytical Chemists, Washington, DC.

Broderick, G.A., and J.H. Kang. 1980. Automated simultaneous determination of ammonia and amino acids in ruminal fluids and in vitro media. J. Dairy Sci. $33: 64-75$.

Arelovich, H.M., C.S. Abney, J.A. Vizcarra, and M.L. Galyean. 2008. Effects of dietary neutral detergent fiber on intakes of dry matter and net energy by dairy and beef cattle: Analysis of published data. Prof. Anim.Sci. 24:375-383.

Balch, C.C. 1952. Factors affecting the utilization of food by dairy cows. 6 . The rate of contraction of the reticulum. Brit. J. Nutr. 6:366-375.

Balch, C.C. 1971. Proposal to use time spent chewing as an index to the extent to which diets for ruminants possess the physical property of fiberousness characteristic of roughages. Brit. J. Nutr. 36:383-392.

Barajas, R., and R.A. Zinn. 1998. The feeding value of dry-rolled and steam-flaked corn in finishing diets for feedlot cattle: Influence of protein supplementation. J. Anim. Sci. 76:1744-1752.

Bartle, S. J., and R.L. Preston. 1991. Dietary roughage regimen for feedlot steers: Reduced roughage level (2\%) during the mid-finishing period. J. Anim. Sci. 69:3461-3466.

Calsamiglia, S., A. Ferret, and M. Devant. 2002. Effect of $\mathrm{pH}$ and $\mathrm{pH}$ fluctuation on microbial fermentation and nutrient flow from a dual-flow continuous culture system. J. Dairy Sci. 85:574-579.

Church, D.C. 1988. The Ruminant Animal Digestive Physiology and Nutrition. Prentice Hall, Englewood Cliffs, NJ.

Crawford, R.J. Jr., W.H. Hoover, and L.L. Junkins. 1980. Effects of solids and liquid flows on fermentation in continuous cultures. II. Nitrogen portioning and efficiency of microbial synthesis. J. Anim. Sci. 51:986-995. 
Cunningham, K.D., M.J. Cecava, and T.R. Johnson. 1993. Nutrient digestion, nitrogen, and amino acid flows in lactating cows fed soybean hulls in place of forage or concentrate. J. Dairy Sci. 76:3523-3535.

Demeyer, D. and C. Van Nevel. 1986. Influence of substrate and microbial interaction on efficiency of rumen microbial growth. Reprod. Nutr. Dev. 26:161-179.

Elstien, D. 2002. Estimating farm animals feed efficiency. www.ars.usda.gov/is/pr/2002/021224.html.

Emmans, G.C. 1994. Effective energy: a concept of energy utilization applied across species. Brit. J. Nutr. 71:801-821.

Evans, E. 1981. An evaluation of the relationship between dietary parameters and rumen solid turnover rate. Can. J. Anim. Sci. 61:97-103.

Firkins, J.L., L.L. Berger, N.R. Merchen, G.C. Fahey, and D.R. Nelson. 1986. Effects of feed intake and protein digestibility on ruminal characteristics and site of digestion in steers. J. Dairy Sci. 69:2111-2123.

Firkins, J.L., W.P. Wess, and E.J. Piwonka. 1992. Quantification of intraruminal recycling of microbial nitrogen using nitrogen-15. J. Anim. Sci. 70:3223-3233.

Firkins, J.L. 1996. Maximizing microbial protein synthesis in the rumen. J. Nutr. 126: 1347S-1354S.

Firkins, J.L., M.S. Allen, B.S. Oldick, and N.R. St-Pierre. 1998. Modeling ruminal digestibility of carbohydrates and microbial protein flow to the duodenum. J. Dairy Sci. 81:3350-3369.

Forbes, J.M. 2000. Physiological and metabolic aspects of feed intake control. p. 319 in Farm Animal Metabolism and Nutrition. J.P.F. D’Mello, ed. CABI Publishing, Wallingford, UK.

Galyean, M.L., and P.J. Defoor. 2003. Effects of roughage source and level on intake by feedlot cattle. J. Anim. Sci. 81(E. Suppl.2):E8-E16.

Garrett, W.N., J.H. Meyer, and G.P. Lofgreen. 1959. The comparative energy requirements of sheep and cattle for maintenance and gain. J. Anim. Sci. 18:528547.

Garrett, W.N., G.P. Lofgreen, and J.H. Meyer. 1964. A net energy comparison of barley and milo for fattening cattle. J. Anim. Sci. 23:470-476. 
Golden, J.W. 2004. RFI and variables line to feed efficiency. MS Thesis. Univ. of Missouri, Columbia.

Golden, J.W. and M.S. Kerley. 2005. Energy required by beef calves was more accurately predicted by effective energy than net energy calculations. J. Anim. Sci. 83(Supp.1):49

Golden J.W. and M.S. Kerley. 2006.

Golden, J.W. and M.S. Kerley. 2008. The relationship of feeding behavior to residual feed intake in crossbred Angus steers fed traditional and no-roughage diets. J. Anim. Sci. 86:180-186.

Grigsby, K.N., M.S. Kerley, J.A. Paterson, and J.C. Weigel. 1992. Site and extent of nutrient digestion by steers fed a low-quality bromegrass hay diet with incremental levels of soybean hull substitution. J Anim. Sci. 70:1941-1949.

Hatfield, R.D. 1993. Cell wall polysaccaharide interactions and degradability. In: Forage cell wall structure and digestibility. Am. Soc. Agron., Crop Sci. Soc. Am., and Soil Sci. Soc. Am., Wadison, WI. Page 285.

Hespell, R.B. and M.P. Bryant. 1979. Efficiency of rumen microbial growth: influence of

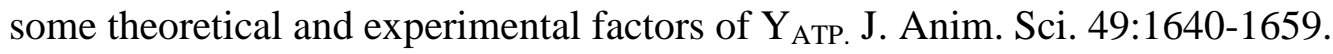

Hoover, W.H., R.J. Crawford Jr., and M.D. Stern. 1982. Effects of solids and liquid flows on fermentation in continuous cultures. III. Solids retention time. J. Anim. Sci. 54:849-854.

Hoover, W.H. 1986. Chemical factors involved in fiber digestion. J. Dairy Sci. 69:27552766.

Kennedy, P.M., R.L. Christopherson, and L.P. Milligan. 1976. The effect of cold exposure of sheep on digestion, rumen turnover time, and efficiency of microbial synthesis. Br. J. Nutr. 36:231-242.

Kennedy, P.M., and L.P. Milligan. 1978. Effects of cold exposure on digestion, microbial synthesis and nitrogen transformation in sheep. Br. J. Nutr. 39:105-117.

Kleiber, M. 1975. The fire of life: an introduction to animal energetic. R.E. Kreiger Publ. Co. New York, N.Y. 453 pp.

Koenig, K.M., C.J. Newbold, F.M. McIntosh, and L.M. Rode. 2000. Effects of protozoa on bacterial nitrogen recycling in the rumen. J. Anim. Sci. 78:2431-2445. 
Kolath, W.H. 2006. The relationship between mitochondria and RFI. Ph.D. Diss. Univ. of Missouri, Columbia.

Lehmkuhler, J.W. 2001. Feedlot cattle responses to ruminally undegradable protein. Ph.D. Diss., Univ. of Missouri, Columbia.

Lofgreen, G.P., D.L. Bath and H.T. Strong. 1963. Net energy of successive increments of feed above maintenance for beef cattle. J. Anim. Sci. 22:598-603.

Lofgreen, G.P. and W.N. Garrett. 1968. A system for expressing net energy requirements and feed values for growing and finishing beef cattle. J. Anim. Sci. 27:793-806.

Loerch, S.C., and F. L. Fluharty. 1998. Effects of programming intake on performance and carcass characteristics of feedlot cattle. J. Anim. Sci. 76:371-377.

Ludden, P.A., and M.S. Kerley. 1997. Amino acid and energy interrelationships in growing beef steers: I. The effect of level of feed intake on ruminal characteristics and intestinal amino acid flows. J. Anim. Sci. 75:2550-2560.

McAllister, T.A., H.D. Bae, G.A. Jones, and K.J. Cheng. 1994. Microbial attachment and feed digestion in the rumen. J. Anim. Sci. 72:3004-3018.

Meng, Q., M.S. Kerley, P.A. Ludden, and R.L. Belyea. 1999. Fermentation substrate and dilution rate interact to affect microbial growth and efficiency. J. Anim. Sci. 77:206-214.

Mueller, A.M. 2004. Emperical equations to predict microbial efficiency. Ph.D. Diss. Univ. of Missouri, Columbia.

Murphy, T.A., and S.C. Loerch. 1994. Effects of restricted feeding of growing steers on performance, carcass characteristics, and composition. J. Anim. Sci. 72:24972507.

NRC. 2000. Nutrient requirements of beef cattle. $8^{\text {th }}$ rev. ed. Natl. Acad. Press, Washington, DC.

NRC. 2001. Nutrient requirements of dairy cattle. $7^{\text {th }}$ rev. ed. Natl. Acad. Press, Washington, DC.

Owens F.N. and H.R. Isaacson. 1977. Ruminal microbial yields: factors influencing synthesis and bypass. Fed. Proc. 36:198-202.

Pearce, G.R. and R. J. Moir. 1964. Rumination in sheep. I. The influence of rumination and grinding upon the passage and digestion of food. Australian J. Agr. Res. 15:635-642. 
Prescott, M.L., J.P. Harley, and D.A. Klein. 1996. Microbiology. ed. E.M. Sievers. Wm. C. Brown publishers, Dubuque, IA. Pp 25-27 and 118-119.

Russell, J.B., J.D. O’Connor, D.G. Fox, P.J. Van Soest, and C.J. Sniffen. 1992. A net carbohydrate and protein system for evaluating cattle diets: I. Ruminal fermentation. J. Anim. Sci. 70:3551-3561.

Russell, J.B., and D.B. Wilson. 1996. Why are ruminal cellulolytic bacteria unable to digest cellulose at low pH? J. Dairy Sci. 79:1503-1509.

Santos, F.A.P., J.E.P. Santos, C.B. Theurer, and J.T. Huber. 1998. Effects of rumenundegradable protein on dairy cow performance: A 12-year literature review. J. Dairy Sci. 81:3182-3213.

Sarwar, M., J.L. Firkins, and M.L. Eastridge. 1992. Effects of varying forage and concentrate carbohydrates on nutrient digestibilities and milk production by dairy cows. J. Dairy Sci. 75:1533-1542.

SAS Version 9.2. 2002-2008. SAS User's Guide. SAS Inst. Inc., Cary, NC.

Schalk, A.F. and R.S. Amadon. 1928. Physiology of the ruminant stomach (bovine). North Dakota Experiment Station Bulletin. 216:1-64.

Slyter, L.L. 1990. Buffers used in the artificial rumen. In: Proc. Continuous Culture Fermenters: Frustration or Fermentation. Northeast ADAS-ASAS Regional Meeting. P 9. Chazy, NY.

Sniffen, C.J., and P.H. Robinson. 1987. Symposium: Protein and fiber digestion, passage, and utilization in lactating cows. J. Dairy Sci. 70:425-441.

Sniffen, C.J., J.D. O’Connor, P.J. Van Soest, D.G. Fox, and J.B. Russell. 1992. A net carbohydrate and protein system for evaluating cattle diets: II. Carbohydrate and protein availability. J. Anim. Sci. 70:3562-3577.

Troelsen, J.E. and F.W. Bigsby. 1964. Artificial mastication - a new approach for predicting voluntary forage consumption by ruminants. J Anim. Sci. 23:11391142.

Tyrrell, H.R., and P.W. Moe. 1975. Effect of intake on digestive efficiency. J. Dairy Sci. 58:1151-1163.

Weston, R.H. and J.P. Hogan. 1967. The digestion of chopped and ground roughages by sheep. I. The movement of digesta through the stomach. Australian J. Agr. Res. 18:789-801. 
Willis, C.A., and M.S. Kerley. 2004. Effect of removing roughage from the diet on digestibility and fermentation characteristics in vivo. J. Anim. Sci. 82(Suppl. 2): 95. (Abstr.)

Zinn, R.A. and F.N. Owens. 1983. Influence of feed intake on site of digestion in steers fed a high concentrate diet. J. Anim. Sci.56:471-475.

Zinn, R.A., E.G. Alvarez, M. Mendez, M.F. Montano, J.E. Ramirez, and Y. Shen. 1997. Influence of dietary sulfur level on growth performance and digestive function in feedlot cattle. J. Anim. Sci. 75:1723-1728.

Zinn, R.A. and Y. Shen. 1998. An evaluation of ruminally degradable intake protein and metabolizable amino acid requirements of feedlot calves. J. Anim. Sci. 76:12801289.

Zinn, R.A., E.G. Alvarez, M.F. Montano, A. Placencia, and J.E. Ramirez. 1998. Influence of tempering on the feeding value of rolled corn in finishing diets for feedlot cattle. J.Anim. Sci. 76:2239-2246. 


\section{VITA}

Joseph Walter Golden was born in Jefferson City, Missouri on July 6, 1980, the son of Joseph and Mary Golden. After graduating from high school at Cole R-5 Eugene in 1998, he attended the University of Missouri-Columbia, receiving his Bachelor of Science degree in Animal Science in 2002, Master of Science degree in 2004 and Doctor of Philosophy under the guidance of Dr. Monty Kerley in 2013. He currently lives in Mountain Grove, MO with his wife Lori and children. 